\title{
Infrações de patente no bojo de Parcerias para o Desenvolvimento Produtivo
}

\author{
Marçal Justen Filho
}

\section{Parecer}

...honrou-me com a solicitação de parecer versando sobre os fatos e os quesitos abaixo expostos.

\section{I - Os fatos e os quesitos}

1. A Consulente narrou ser titular da patente de invenção ..., concedida pelo Instituto Nacional da Propriedade Industrial (INPI). ...

2. Segundo informado pela Consulente, ... o registro sanitário foi concedido pela ANVISA em ... à ... - única empresa autorizada pela Consulente a explorar o objeto da patente no Brasil.

3. Ocorre que, a despeito dos fatos acima narrados, foram apresentadas e aprovadas propostas de contratos administrativos de Parcerias para o Desenvolvimento Produtivo (PDP), envolvendo pessoas jurídicas privadas e públicas não autorizadas a explorar o objeto da patente, tendo por escopo a aquisição de tal medicamento a base de ..., a transferência de tecnologia para a sua produção e a sua fabricação em território nacional.

4. Em face desses fatos, a Consulente reputa que a submissão de uma proposta de contrato administrativo de PDP, tendo por objeto a aquisição de unidades do medicamento que faz uso de invento patenteado, infringe as normas dos 
arts. 42 e 184 da Lei da Propriedade Industrial - LPI (Lei Federal 9.279/1996) bem como dos arts. 14, III, b e 22, VIII da Portaria 2.531/2014 do Ministério da Saúde.

5. Assim e para respaldar o seu posicionamento, solicitou a elaboração do presente parecer, versando sobre os seguintes quesitos:

a) O direito brasileiro assegura ao titular de patente de invenção, durante seu prazo de vigência, o direito de impedir terceiros de produzir, usar, colocar à venda, vender ou importar com estes propósitos (Art. 42 da LPI), bem como de fabricar (Art. 183 da LPI), exportar, vender, expor ou oferecer à venda, ter em estoque, ocultar ou receber, para utilização com fins econômicos (Art. 184 da LPI), medicamento que faz uso de invento objeto de patente?

b) A oferta à venda de medicamento que faz uso de um invento que é objeto de patente, quando não envolve o seu titular ou agente legitimamente autorizado (i.e. por meio de licença), configura ato jurídico ilícito?

c) No direito brasileiro, em que a oferta à venda de produto objeto de patente é autonomamente tipificada como crime (art. 184 da LPI) e ato ilícito civil (art. 42 da LPI), a configuração da ilicitude requer a comprovação de que a venda se consumaria na vigência da patente ou a oferta à venda já caracteriza per se infração ao direito patentário?

d) A prática de atos como a importação, a fabricação e a manutenção em estoque de produto objeto de patente configura ato jurídico ilícito segundo a legislação brasileira, mesmo se a sua comercialização estiver programada para ocorrer apenas após finda a proteção patentária?

e) É compatível com o direito brasileiro a celebração de PDP para a aquisição de medicamento que faz uso de invento objeto de patente e a transferência de tecnologia para sua produção, com terceiros não autorizados?

f) Uma proposta de PDP que cumpra com as diretrizes e requerimentos da Portaria 2.531 de 12 de novembro de 2014 do Ministério da Saúde, como aqueles elencados em seu artigo 14, VIII, configuraria uma "oferta à venda" nos termos da Lei 9.279/1996?

g) A formalização e ratificação de proposta de PDP aprovada, por meio da assinatura de Termo de Compromisso (art. 35 da Portaria 2.531), evidencia o aceite da "oferta à venda" nos termos da Lei 9.279/1996?

6. Passo a responder. 


\section{II - A ressalva inicial}

7. Alguns dos temas pertinentes à controvérsia já foram objeto de análise pelo signatário em oportunidades pretéritas. No presente parecer, tais entendimentos são reiterados e ratificados.

\section{III - Considerações gerais sobre a propriedade imaterial}

8. A expressão "propriedade imaterial" tem sido utilizada para indicar relações jurídicas que asseguram a titularidade de poderes jurídicos de um sujeito sobre objetos destituídos de existência física, resultantes de criações imateriais produzidas pelo ser humano.

\section{III.1 A questão da propriedade}

9. A propriedade imaterial não se confunde com o instituto da propriedade ou do domínio, embora com ele guarde pontos de contato relevantes.

\section{III.1.1 As características quanto ao objeto protegido}

10. A propriedade, tal como tradicionalmente conhecida no direito privado e cujo tratamento jurídico remonta (pelo menos) ao direito romano, versa sobre objetos dotados de existência física. Na sua origem, a propriedade envolvia o apossamento pelo ser humano de um objeto da Natureza. Ao longo do tempo, passou a se admitir a propriedade envolvendo criações do ser humano, mas sempre com o pressuposto da existência de um objeto que ocupasse lugar no espaço.

11. Já a propriedade imaterial é uma decorrência do desenvolvimento pelo ser humano de atividades criativas, em que a fisicalidade é uma circunstância não necessária. $\mathrm{O}$ fundamental reside na capacidade humana de produzir novos inventos, signos distintivos e criações autorais.

12. Nesse caso, a criação inerente à propriedade imaterial pode traduzir-se em objetos físicos. Mas não se confunde o objeto da propriedade imaterial e a 
coisa física dela decorrente. Assim, por exemplo, suponha-se uma composição musical, que pode ser objeto de propriedade imaterial em favor do autor. Mas o objeto protegido pelo direito não se confunde com a base física em que se armazena a reprodução da composição. A composição musical não se confunde com o CD (para utilizar uma figura obsoleta) em que está gravada uma interpretação. Igualmente, a obra literária não se confunde com o exemplar do livro que a reproduz.

13. Então, o livro e o $C D$, nos exemplos, serão objeto de propriedade tradicional. Alguém será "dono" desses objetos. Mas a obra literária e a composição musical são objeto de uma proteção jurídica distinta - e o serão na sua dimensão imaterial, como criações do espírito humano.

\section{III.2 A distinção entre direitos autorais e propriedade industrial}

14. Usualmente, considera-se que a propriedade imaterial compreende uma pluralidade de situações distinguíveis entre si. Basicamente, são diferenciadas a propriedade intelectual e a propriedade industrial. ${ }^{1}$

\section{III.2.1 Os direitos autorais}

15. Alude-se à propriedade intelectual para indicar as criações preponderantemente artísticas, que refletem a inovação não orientada propriamente a transformar a realidade existencial, mas a explorar essencialmente a dimensão estética.

\footnotetext{
A distinção entre direitos autorais e propriedade industrial já foi mais simples no passado. A evolução civilizatória conduziu à incorporação da arte no âmbito das atividades econômicas. Como decorrência, a propriedade intelectual permite a exploração empresarial em termos muito similares ao que se passa com a propriedade industrial. O tema foi objeto de análise percuciente de Giles Lipovestky e Jean Serroy, que destacam: "o capitalismo artista criou um império transestético proliferante em que se misturam design e star-system, criação e entertainment, cultura e show business, arte e comunicação, vanguarda e moda" (A estetização do mundo - viver na era do capitalismo artista. Tradução de Eduardo Brandão. São Paulo: Companhia das Letras, 2015. p. 28).
} 


\section{III.2.2 A propriedade industrial}

16. A propriedade industrial compreende inovações destinadas especificamente a produzir um resultado material útil, refletindo a utilização do conhecimento científico para utilização tecnológica. ${ }^{2}$

\section{III.3 Os direitos assegurados ao titular da propriedade imaterial}

17. A propriedade imaterial atribui ao seu titular as faculdades de usar, fruir e dispor do objeto, assim como de impedir que outro sujeito dele se valha de modo indevido.

\section{III.3.1 As utilidades diretas em favor do titular}

18. É assegurado ao titular da propriedade imaterial a utilização direta ou indireta do objeto. Isso compreende o poder jurídico de usar para si mesmo, tal como lhe é assegurado também a coleta dos seus frutos. Ademais, também lhe é facultado dispor dos benefícios econômicos decorrentes, promovendo a transferência da sua titularidade para terceiros - mediante, se assim the aprouver, remuneração adequada.

\section{III.3.2 A vedação à apropriação por terceiros}

19. Um dos atributos essenciais à propriedade imaterial consiste no poder jurídico assegurado ao titular de impedir que terceiros se valham do seu objeto sem a sua concordância. Essa questão é extremamente relevante, eis que a ausência de materialidade física do objeto do direito imaterial dá oportunidade à sua exploração por um terceiro, de modo indevido.

2 A propriedade industrial é um instituto compreendido no âmbito do direito empresarial. Para uma análise clássica do tema, consulte-se Gama Cerqueira, Tratado da propriedade industrial. São Paulo: RT, 1982. 


\section{III.3.3 O direito de o titular exigir a cessação da exploração indevida}

20. Por isso, uma das características jurídicas essenciais da propriedade imaterial consiste no poder jurídico de o titular obter medidas jurídicas destinadas a fazer cessar a atuação indevida do terceiro. Essa solução é indispensável à preservação da identidade do objeto da propriedade imaterial.

\section{III.3.4 A relevância diferenciada no âmbito da propriedade industrial}

21. Esse atributo apresenta relevância ainda mais significativa no âmbito da propriedade industrial. Assim se passa porque o objeto da propriedade industrial envolve precisamente a produção de efeitos materiais diferenciados, que apresentam relevância econômica específica.

\section{IV - A garantia constitucional às patentes de invenção}

22. A relevância socioeconômica das criações imateriais, especialmente no âmbito da propriedade industrial, conduziu à tutela constitucional à inovação.

\section{IV.1 A tradição constitucional brasileira}

23. A CF/88 manteve a tradição constitucional brasileira de expressa tutela à propriedade industrial no âmbito dos direitos e garantias fundamentais.

\section{IV.2 A propriedade como direito fundamental}

24. Sob um prisma geral, a propriedade é reconhecida constitucionalmente como um direito fundamental. Há diversas passagens no art. 5o da CF/88 assegurando proteção ampla à propriedade. Aliás, tal previsão está contemplada no próprio caput do art. 5ํㅜ da CF/88. 


\section{IV.3 A previsão explícita sobre os inventos industriais}

25. Para evitar controvérsia sobre a extensão da garantia à propriedade industrial, a CF/88 contemplou regra específica. O art. 5\%, inc. XXIX, determina que "a lei assegurará aos autores de inventos industriais privilégio temporário para sua utilização ..., tendo em vista o interesse social e o desenvolvimento tecnológico e econômico do País".

\section{IV.4 A tutela à atividade econômica privada}

26. Por outro lado, há tutela constitucional à exploração das atividades econômicas pelos particulares, contemplada em uma pluralidade de dispositivos. Basta destacar o art. 170 e seu parágrafo único da $\mathrm{CF} / 88$, que reconhecem a livre-iniciativa, a livre concorrência e a legitimidade da apropriação privada dos lucros produzidos.

27. Os inventos industriais se constituem em instrumento relevante (se não indispensável) para o progresso econômico. Tal como se extrai da experiência civilizatória, a tutela às invenções está presente em todos os países socioeconomicamente desenvolvidos. Por isso, deve-se reputar que a proteção constitucional à exploração das atividades econômicas pelos particulares compreende inclusive garantias em favor dos autores de inventos.

\section{V - A saúde como direito fundamental e a Administração Pública}

28. A questão comporta enfoque sob outro prisma, relacionado com as hipóteses em que o invento versar sobre medicamentos e outros produtos relacionados com a saúde humana.

\section{V.1 A proteção constitucional à vida (e à saúde)}

29. Os direitos fundamentais são manifestações distintas da relevância à dignidade humana. Como é evidente, um direito fundamental essencial consiste na proteção à saúde. 


\section{V.1.1 A atividade farmacêutica e a proteção à saúde}

30. Existe uma evidente relação entre a atividade farmacêutica e a proteção à saúde. Os medicamentos são úteis e necessários - algumas vezes, indispensáveis - à prevenção de doenças, ao tratamento das moléstias e à ampliação da qualidade de vida.

\section{V.1.2 A dignidade humana e os medicamentos}

31. Os medicamentos são instrumento de combate a doenças, de prevenção da deterioração da integridade física e mental e de atenuação do sofrimento gerado por fatores externos e internos.

32. Os medicamentos são fundamentais para a melhoria da saúde dos seres humanos. A administração de medicamentos destina-se a prevenir moléstias e seus efeitos danosos, bem como a promover a cura dos pacientes. Em muitos casos, o medicamento é a única alternativa para assegurar o tratamento ou melhorar a qualidade de vida do paciente. Em outros, assume papel fundamental no combate à disseminação de uma moléstia para o conjunto da sociedade. ${ }^{3}$

33. Sob qualquer ângulo, o medicamento é um meio de promover a dignidade humana, nas suas mais diversas facetas. Nos últimos séculos, o avanço científico e a evolução da medicina resultaram na ampliação da expectativa e da qualidade de vida do ser humano, graças especialmente à prevenção e ao tratamento de doenças por meio de medicamentos.

34. A fundação da Organização Mundial da Saúde, em 1946, estabeleceu um marco na promoção da saúde. A Constituição da OMS consagra a saúde como "um estado de completo bem-estar físico, mental e social e não apenas a ausência de doença ou enfermidade". ${ }^{4}$ Ficou estabelecido que gozar do melhor estado de saúde possível é um direito fundamental de todo o ser humano.

3 A título de exemplo, tome-se o surto do vírus ebola, que registrou milhares de mortes em um período de meses, principalmente na África. Até o momento, nenhuma medida efetiva para evitar a disseminação do vírus foi encontrada. Os especialistas apontam que uma vacina, que vem sendo desenvolvida por laboratórios farmacêuticos, é o mecanismo mais eficiente para conter a contaminação em larga escala. Confira-se: <www.sbmt.org.br/portal/ebola-apos-40anos-finalmente-temos-uma-vacina-eficaz-contra-a-doenca/>.

4 Fonte: <www.direitoshumanos.usp.br/index.php/OMS-Organiza\%C3\%A7\%C3\%A3 ${ }^{\circ}$-Mun dial-da-Sa\%C3\%BAde/constituicao-da-organizacao-mundial-da-saude-omswho.html>. Acesso em: 8 abr. 2018. 


\section{V.1.3 O dever estatal de promover a saúde}

35. A promoção da saúde se constitui em um direito fundamental, ao qual corresponde (inclusive) um dever estatal. Uma síntese da disciplina constitucional sobre o tema se encontra no art. $196 \mathrm{da} \mathrm{CF} / 88$, assim redigido:

A saúdeé direito de todos e dever do Estado, garantido mediante políticas sociais e econômicas que visem à redução do risco de doença e de outros agravos e ao acesso universal e igualitário às ações e serviços para sua promoção, proteção e recuperação.

36. Mas seria um equívoco hermenêutico muito grave extrair desse dispositivo a conclusão de que o Estado seria titular privativo das atividades de natureza farmacêutica.

\section{V.2 A orientação geral: a ausência de monopólio estatal}

37. A consagração constitucional de um direito fundamental e do dever de o Estado promover ações necessárias à dignidade humana não acarreta, como decorrência jurídica necessária, o surgimento de monopólio estatal na área específica.

38. Essa é a orientação geral da $\mathrm{CF} / 88$, que se manifesta relativamente a diversos outros setores, não apenas no âmbito da saúde. Assim, por exemplo, mais relevante do que o medicamento para a preservação da saúde é a alimentação. Portanto, o direito fundamental à saúde implica não apenas o fornecimento de medicamentos para os indivíduos. Mais do que isso, demanda a alimentação adequada. Mas ninguém ousaria afirmar que a produção ou a comercialização de alimentos teriam sido transformadas constitucionalmente em monopólio estatal.

\section{VI - A exploração econômica em regime de mercado}

39. Verificou-se, então, que a solução mais satisfatória e eficiente reside em reconhecer à iniciativa privada a autonomia para aplicar os métodos de mercado para a concepção, o desenvolvimento, a produção e a comercialização dos medicamentos. 


\section{VI.1 A exploração mais eficiente dos recursos econômicos}

40. Isso permite a alocação dos recursos econômicos privados para o desenvolvimento de todas essas atividades. A competição entre os diversos agentes econômicos, visando à obtenção de lucro, conduz ao surgimento de novos medicamentos, a partir de ideias originais que resultam em soluções até então não cogitadas.

41. A solução mais eficiente para o surgimento de novos medicamentos, com o custo mais reduzido e no menor espaço de tempo, reside em facultar à iniciativa privada a exploração dessas atividades.

\section{VI.2 O desenvolvimento de novos medicamentos}

42. Os laboratórios farmacêuticos têm um papel essencial no desenvolvimento de novos medicamentos.

43. A maior parte dos medicamentos que depois se tornam disponíveis no mercado surge por meio da atuação de laboratórios farmacêuticos. A indústria investe valores vultosos nesse campo, com vistas a desenvolver produtos para as mais diferentes doenças e moléstias.

44. O retorno financeiro do investimento em pesquisa e desenvolvimento advém da comercialização de medicamentos. Ou seja, a venda dos medicamentos é necessária para sustentar o custo e os riscos da pesquisa e desenvolvimento para a produção de novos produtos.

\section{VI.2.1 $\bigcirc$ custo elevado das pesquisas}

45. O processo criativo de novos medicamentos apresenta custos extremamente elevados. Isso porque o período de tempo despendido entre o início das pesquisas científicas e a produção e posterior comercialização de um medicamento é prolongado. Estima-se que o prazo de desenvolvimento científico para a criação de um medicamento novo seja, em média, de dez anos. ${ }^{5}$

5 Bruno Falcone, Propriedade industrial \& defesa da concorrência: convergência principiológica. Curitiba: Juruá, 2013. p. 66. 
46. O custo aproximado para o desenvolvimento de um medicamento novo pode variar de 800 milhões a 2,6 bilhões de dólares. ${ }^{6}$

\section{VI.2.2 Os riscos de insucesso}

47. Esse custo torna-se mais significativo ainda ao se considerar que a probabilidade de êxito no desenvolvimento de medicamentos é bastante reduzida. Trata-se de processo que envolve um grau elevado de riscos e incertezas. Apenas uma pequena parcela dos compostos desenvolvidos tem a sua eficácia comprovada e o seu uso aprovado, chegando ao mercado na forma de medicamento. São significativas as chances de o resultado final de determinado processo inventivo fracassar.

48. Nesses casos, o laboratório desenvolvedor terá que arcar integralmente com todos os custos desse processo, sem ter a possibilidade de obter qualquer recompensa direta pelos recursos e esforços empregados.

\section{VI.2.3 A exploração econômica do medicamento}

49. Os custos totais no desenvolvimento de novos produtos são compensados por meio da comercialização dos medicamentos no mercado. Os resultados econômicos da exploração do medicamento asseguram à indústria de pesquisa e desenvolvimento a amortização de seus custos, o custeio de suas despesas e a remuneração ao capital investido.

\section{VI.2.4 A exigência inafastável da tutela à propriedade industrial}

50. Esses pressupostos conduzem à exigência inafastável da tutela própria à invenção. A submissão das invenções relacionadas a medicamentos ${ }^{7}$ ao regime

6 Nesse sentido, DI BLASI, Gabriel. A propriedade industrial: os sistemas de marcas, patentes e desenhos industriais analisados a partir da Lei 9.279, de 14 de maio de 1996, Rio de Janeiro: Forense, 2005.p. 42; e Bruno Falcone, Propriedade..., op. cit., p. 67.

7 No presente parecer, há reiteradas passagens aludindo a patentes sobre "medicamentos". Essa terminologia simplificada não afasta o reconhecimento de que a Lei de Propriedade Industrial alude a produtos e/ou processos farmacêuticos. Por outro lado, existem diversas patentes que cobrem diferentes aspectos de um medicamento ou de seu modo de produção. Mas o princípio ativo do medicamento só pode ser objeto de uma patente. 
da propriedade industrial é essencial e indispensável à própria existência da indústria farmacêutica.

51. A ausência ou a limitação de patentes de invenção sobre tecnologias relacionadas a medicamentos conduziria à apropriação dos benefícios por qualquer terceiro, que poderia beneficiar-se dos esforços, dos investimentos e da genialidade alheia. Diante da inviabilização da recuperação dos investimentos, haveria um incentivo insuperável à cessação das atividades de pesquisa e inovação nesse setor.

52. Defender a eliminação das patentes de medicamentos acarretará efeitos muito mais danosos à saúde pública e individual. Promover a violação dos direitos protegidos pela patente resultará, em curto prazo, na ausência de instrumentos para prevenção e tratamento de moléstias.

53. Portanto, a proteção jurídica aos interesses econômicos da indústria farmacêutica de pesquisa e desenvolvimento é condição indispensável à sua existência. Aliás, assim se passa com toda e qualquer atividade econômica. A remuneração se constitui em contrapartida essencial pela aplicação de recursos e esforços pessoais.

\section{VI.2.5 A solução legislativa expressa}

54. Essas razões (dentre outras) conduziram à adoção de uma solução legislativa explícita. A Lei 9.279 admite a patenteabilidade de invenções relativas a produtos farmacêuticos, desde que atenda aos requisitos de novidade, atividade inventiva e aplicação industrial (art. $8^{\circ}$ ).

55. Ao revogar o Código da Propriedade Industrial (Lei 5.772/1971), a Lei 9.279 acabou com a vedação expressa à concessão de patentes tendo por objeto produtos e processos farmacêuticos.

56. Tanto se admite a patenteabilidade de inventos farmacêuticos, que a Lei de Propriedade Industrial prevê expressamente a participação da ANVISA em pedidos dessa área tecnológica. ${ }^{8}$

57. É inquestionável, portanto, que os inventos farmacêuticos constituem matéria patenteável no Brasil, incidindo a proteção jurídica correspondente.

8 Lei de Propriedade Industrial, art. 229-C: “A concessão de patentes para produtos e processos farmacêuticos dependerá da prévia anuência da Agência Nacional de Vigilância Sanitária ANVISA". 


\section{VI.3 A indústria farmacêutica como atividade econômica}

58. Em conclusão, a indústria farmacêutica configura-se como uma atividade econômica aberta à iniciativa privada e à livre concorrência, com todos os instrumentos jurídicos pertinentes - inclusive a tutela inerente à propriedade industrial.

\section{VI.3.1 A incidência das garantias constitucionais pertinentes}

59. Todas as garantias constitucionais à atividade econômica se aplicam à atividade farmacêutica. Isso significa a incidência das normas constitucionais de proteção à propriedade privada, à livre-iniciativa e à livre concorrência.

\section{VI.3.2 A ilicitude da infração à patente de invenção}

60. Não é lícita qualquer atividade - pública ou privada - orientada a violar os direitos resultantes de patente de invenção, inclusive de patentes que protejam produtos farmacêuticos.

\section{VII — Patentes de invenção e a administração pública}

61. Seria até desnecessário assinalar que as patentes de invenção e todo o regime jurídico acima delineado são oponíveis inclusive à Administração Pública. Ou seja, as regras referidas não têm âmbito de aplicação restrito apenas aos sujeitos privados.

\section{VII.1 O regime constitucional da Administração Pública}

62. A atividade administrativa é subordinada, no Brasil, a um regime jurídico severo, que não comporta qualquer prática apta a colocar em risco valores fundamentais. 


\section{VII.1.1 O art. $37 \mathrm{da} C F / 88$}

63. $\mathrm{O}$ art. 37 da CF/88 estabelece que "A administração pública direta e indireta de qualquer dos Poderes da União, dos Estados, do Distrito Federal e dos Municípios obedecerá aos princípios de legalidade, impessoalidade, moralidade, publicidade e eficiência...".

\section{VII.1.2 A relevância à legalidade}

64. A legalidade se constitui em um dos fundamentos do regime de direito público. A determinação constitucional é inerente a um Estado de Direito, em que a atividade estatal é disciplinada pelo Direito. Os atos administrativos não se encontram fora da esfera jurídica. A conduta dos agentes públicos não está acima do ordenamento jurídico. Exige-se a compatibilidade entre o agir administrativo e o ordenamento jurídico.

\section{VII.2 Ainda a distinção entre regimes jurídicos}

65. O direito brasileiro submete a atividade administrativa ao regime de direito público. Já os particulares estão sujeitos ao regime de direito privado. A distinção entre os dois regimes reflete as finalidades a que são orientadas as atividades públicas e privadas.

66. A atividade administrativa é norteada à realização de valores indisponíveis, que traduzem conquistas civilizatórias que dão identidade à Nação. A indisponibilidade de tais valores conduziu à atribuição à Administração Pública da titularidade do poder-dever de promover a sua realização efetiva. ${ }^{9}$ 67. Já a atividade privada é orientada pela autonomia quanto à escolha de fins e dos meios para a sua realização. Os sujeitos privados são titulares, na maior parte dos casos, da faculdade de escolher os fins que nortearão a atividade própria. Isso compreende, inclusive, o poder para alterar as suas escolhas, sacrificar o seu patrimônio, adotar decisões sujeitas a uma lógica pessoal.

9 Existe uma imprecisão terminológica quando se afirma que "o interesse públicoé indisponível". Um interesse é publicizado por ser indisponível. Portanto, antes de ser público, o interesse é indisponível. A indisponibilidade é a causa, a consequência é a sua publicização. Usualmente, os interesses indisponíveis são atribuídos ao Estado, mas há muitas hipóteses em que o sujeito privado assume a sua titularidade. O exemplo mais evidente é o poder parental. 


\section{VII.2.1 O respeito ao direito: o princípio da legalidade}

68. Um potencial equívoco reside em afirmar que uma das características diferenciais do regime de direito público é a submissão ao princípio da legalidade. Esse tipo de afirmativa implica a concepção de que o regime de direito privado não comportaria submissão ao princípio da legalidade. Haverá equívoco se essa construção refletir o entendimento de que o regime de direito privado legitima a conduta ilícita e a infração à lei.

69. Ora, é evidente que a compatibilidade com o direito (e com a lei) constituem-se em núcleo essencial tanto do regime de direito público como do regime de direito privado. Exige-se que todas as condutas intersubjetivas, sejam elas desenvolvidas no âmbito do Estado ou fora dele, sejam compatíveis com os valores jurídicos fundamentais.

\section{VII.2.2 A exigência generalizada de respeito aos valores fundamentais}

70. O núcleo da distinção entre os regimes de direito público e de direito privado não reside, por isso, no respeito à lei - exigência comum a qualquer conduta socialmente relevante. ${ }^{10}$

\section{VII.2.3 O núcleo da distinção}

71. A diferença fundamental reside em que toda e qualquer conduta subordinada ao direito público apresenta natureza instrumental para a realização dos valores fundamentais.

72. Já as condutas disciplinadas pelo direito privado são orientadas à realização dos direitos individuais - o que não significa autorização para lesar a ordem jurídica.

73. A distinção reside em que a margem de autonomia para o agente público é muito mais restrita do que aquela reconhecida ao sujeito privado.

10 Considerações similares são aplicáveis ao tema da submissão ao princípio da boa-fé, que se constitui num dos fundamentos tanto do regime jurídico de direito público quanto do direito privado. A violação à boa-fé é uma infração muito séria em qualquer hipótese, seja tal prática imputada à Administração Pública ou a um sujeito privado. 
74. Assim se passa porque a renúncia pelo agente privado à realização dos próprios interesses não se constitui em infração à ordem jurídica. Diversamente se passa no tocante ao agente público, que somente pode abdicar da realização dos valores fundamentais quando houver uma autorização legislativa para isso.

75. É nesse sentido que se afirma que, no âmbito privado, o particular pode fazer ou deixar de fazer tudo aquilo que não for proibido pelo direito, enquanto o agente público apenas pode fazer ou deixar de fazer aquilo que lhe for permitido.

76. É evidente que isso não significa que os agentes públicos ou privados teriam a faculdade de fazer algo que a lei proíbe ou deixar de fazer algo que a lei determina. As normas proibitivas e imperativas aplicam-se com idêntica eficácia para os setores públicos e privados.

77. Sintetizando, com palavras diversas aquilo que já foi exposto, a distinção reside em que o regime de direito privado não exige uma autorização normativa formal para que o sujeito escolha os fins e os meios quanto à sua conduta. Já o regime de direito público exige uma autorização normativa para que o agente escolha um fim ou um meio diverso daquele previsto normativamente.

\section{VII.3 A Administração Pública e os direitos subjetivos privados}

78. As considerações anteriores tornam evidente que a atividade administrativa do Estado encontra-se conformada não apenas pelas normas dirigidas diretamente à sua atuação. Também se exige a sua conformidade com os direitos subjetivos de natureza privada.

\section{VII.3.1 Estado Democrático de Direitos e garantias aos particulares}

79. Uma das características essenciais do Estado Democrático de Direito reside na consagração de garantias em favor dos particulares, que são oponíveis ao próprio Estado.

80. Aliás, essa concepção se encontra na própria origem do Constitucionalismo do século XVIII. As primeiras Constituições contemplaram não apenas a separação dos Poderes estatais, mas também as limitações do poder estatal em face dos particulares. 
81. Justamente por isso, o constitucionalismo contemporâneo reconhece que a primeira geração dos direitos fundamentais envolve as posições subjetivas oponíveis diretamente ao Estado. ${ }^{11}$ Relacionam-se com a vida, a propriedade, a liberdade de pensamento, dentre outras manifestações fundamentais.

\section{VII.3.2 A criação de direitos subjetivos por via legislativa}

82. Mas o elenco de posições subjetivas oponíveis ao Estado não se restringe aos direitos fundamentais. Há uma pluralidade de direitos subjetivos instituídos por meio de lei infraconstitucional, que têm como sujeito ativo um sujeito privado. Em alguns casos, o sujeito passivo de tais posições jurídicas é outro sujeito privado. Em outras hipóteses, há um direito subjetivo exercitável especificamente em face do Estado. E existem situações em que os direitos subjetivos são oponíveis erga omnes - o que significa que também o Estado se subordina aos respectivos efeitos jurídicos.

\section{VII.3.3 Os direitos subjetivos privados e a legalidade administrativa}

83. Nas hipóteses em que o direito subjetivo privado é oponível exclusivamente ao Estado ou em que é dirigido erga omnes, a determinação constitucional da legalidade impõe limites à atuação estatal.

84. A vedação à infração às determinações consagradas normativamente impõe ao Estado o dever jurídico de respeitar o conteúdo dos direitos subjetivos assegurados ao sujeito privado.

\section{VII.4 A vedação à prática de infração pela Administração Pública}

85. As peculiaridades do regime de direito público que disciplinam a atividade da Administração Pública implicam a vedação à prática por ela de qualquer conduta tendente a infringir os direitos assegurados por patente de invenção.

11 Acerca da concepção geracional dos direitos fundamentais, consulte-se a obra de Paulo Bonavides, Curso de direito constitucional. São Paulo: 2013. Lembre-se que a distinção entre as diversas gerações de direitos fundamentais não significa que somente aqueles de primeira geração sejam oponíveis ao Estado. Ocorre que esses direitos fundamentais de primeira geração são especificamente orientados a proteger o indivíduo em face do Estado. 


\section{VII.4.1 A responsabilidade civil objetiva da Administração Pública}

86. Um dos aspectos centrais do regime de direito público consagrado constitucionalmente reside na responsabilidade civil objetiva. $\mathrm{O}$ art. $37, \S 6^{\circ}$, da CF/88 estabelece que

As pessoas jurídicas de direito público e as de direito privado prestadoras de serviços públicos responderão pelos danos que seus agentes, nessa qualidade, causarem a terceiros, assegurado o direito de regresso contra o responsável nos casos de dolo ou culpa.

87. Essa regra submete a Administração Pública a uma disciplina mais severa do que a aplicável à generalidade dos sujeitos. A violação objetiva ao direito, quando acarretar lesão a terceiro, imporá a indenização pela Administração Pública das perdas e danos causados.

\section{VII.4.2 O impedimento à prática da ilicitude pela Administração Pública}

88. A imposição da legalidade da atividade administrativa do Estado acarreta impedimento à consumação do ilícito. $\mathrm{O}$ direito prevê mecanismos para preservar a integridade do ordenamento. Autorizam-se providências orientadas a interromper o curso da atividade administrativa orientada à violação ao direito.

89. Justamente por isso, o direito brasileiro contempla uma série de remédios jurisdicionais e administrativos de natureza acautelatória e preventiva, destinados a evitar a consumação da ilicitude ou do abuso.

\section{VII.5 A gravidade diferenciada da ilicitude administrativa}

90. A tese da legitimidade da ilicitude administrativa é teratológica inclusive porque tais categorias de condutas são dotadas de reprovabilidade diferenciada. 


\section{VII.5.1 A dimensão preventiva da sanção jurídica}

91. Toda sanção jurídica apresenta uma dimensão de prevenção, o que não exclui outras finalidades. A disciplina jurídica é norteada a evitar a consumação de infrações. Portanto, a sanção (inclusive a responsabilidade civil de cunho indenizatório) apresenta essa feição de desestímulo ao ato ilícito.

92. Em vista da impossibilidade fática de eliminar a ilicitude, a sanção jurídica também se destina à reparação dos efeitos nocivos produzidos e à punição do infrator. Daí não se segue, no entanto, que o ordenamento jurídico institua um "direito subjetivo" de delinquir mediante a assunção dos efeitos da sanção. Se, num caso concreto, a sanção for destituída de eficácia dissuasória, configurase um grave defeito técnico-jurídico.

\section{VII.5.2 A gravidade da ilicitude administrativa}

93. Mas apenas se pode conceber um defeito técnico-jurídico, tal como acima referido, no âmbito das condutas privadas. No tocante à atividade administrativa, é indefensável a concepção de que o agente estatal disporia da faculdade de descumprir o direito e infringir direitos subjetivos alheios, bastando arcar com os efeitos patrimoniais decorrentes de uma indenização.

94. Essa solução é absolutamente incompatível com um Estado Democrático de Direito. O Estado se subordina ao Direito e todos os agentes estatais estão constrangidos a respeitar as normas jurídicas. A consumação de tais ilicitudes no âmbito administrativo coloca em risco as instituições políticas essenciais, produzindo a redução da legitimidade das instituições. Ou seja, há uma gravidade político-institucional na conduta consciente e intencional do agente estatal de lesar o direito.

\section{VII.5.3 A dimensão ética da conduta estatal}

95. Sob outro prisma, o Estado Democrático de Direito é submetido a exigências éticas. É incompatível com a ordem institucionalizada que um agente estatal oriente a sua conduta de modo a produzir a violação ao direito. Prática dessa ordem infringe o compromisso fundamental entre Estado e Nação. 


\section{VII.5.4 A ausência de titularidade patrimonial}

96. A questão é ainda mais séria porque os efeitos patrimoniais da ilicitude praticada pelo agente administrativo recaem sobre o erário. O Estado responde civilmente pelas ações e omissões de seus agentes. Ainda que esteja previsto o direito de regresso em favor do Estado, isso não elimina os efeitos danosos produzidos pela conduta infracional.

\section{VII.5.5 Síntese: a vedação à consumação da ilicitude}

97. O disposto no $\S 6^{\circ}$ do art. 37 da CF/88 não significa uma forma de autorização para a prática do ilícito pela Administração Pública. Não é cabível defender que a Constituição teria legitimado a infração do direito mediante a garantia da indenização ao particular lesado. Essa solução seria teratológica.

98. O princípio da legalidade acarreta uma vedação geral e absoluta à conduta ilícita do agente público. A Administração Pública não dispõe de autonomia jurídica para violar a lei e infringir direitos assegurados a terceiros.

\section{VII.6 A submissão da Administração Pública aos efeitos da patente}

99. A consagração formal do direito de patente, no âmbito dos produtos e processos farmacêuticos, produz efeitos vinculantes para a Administração Pública.

\section{VII.6.1 A oponibilidade da patente à Administração Pública}

100. A patente é oponível à Administração Pública por se tratar de um direito subjetivo formalmente reconhecido pelo direito em favor de um particular, oponível a pessoas indeterminadas. A Administração Pública não é investida de poder jurídico para furtar-se aos efeitos da patente. 


\section{VII.6.2 O dever jurídico de abster-se de condutas infracionais}

101. Por decorrência, há um dever jurídico recaindo sobre todos os agentes públicos tendo por objeto a abstenção de qualquer conduta apta a infringir os direitos assegurados ao titular de uma patente de invenção.

\section{VII.7 Ainda os limites da "supremacia do interesse público"}

102. A outorga de patente a um particular, tendo por objeto um produto ou processo farmacêutico, afasta a incidência do princípio da "supremacia do interesse público". ${ }^{12}$

\section{VII.7.1 A eficácia vinculante do direito subjetivo privado}

103. A proteção normativa formal ao sujeito privado, que se traduz na existência de um direito subjetivo, apresenta eficácia vinculante inclusive para a Administração Pública.

104. A eventual existência de um interesse de titularidade da Administração Pública não é suficiente para eliminar a tutela normativa inerente à figura do direito subjetivo.

105. Qualquer consideração em contrário violaria o princípio da separação dos Poderes. Se a Administração está sujeita à lei e se uma lei assegura um direito subjetivo a um particular, não há fundamento para que a Administração ignore ou se sobreponha ao dito direito subjetivo.

106. Em outras palavras, a eficácia jurídica do "interesse público" não se sobrepõe àquela da lei. Se a lei assegurou uma posição jurídica ao particular, cabe à Administração Pública respeitar e obedecer tal determinação.

12 O signatário não é partidário da concepção de que o princípio da supremacia do interesse público seria um dos alicerces do regime de direito público. Sobre o tema, confira-se o entendimento do signatário em Curso de direito administrativo. São Paulo: RT, 2016. p. 51 e ss. 


\section{VII.7.2 O âmbito de aplicação da supremacia do interesse público}

107. Se a lei veicular uma solução jurídica específica, o interesse público consiste em promover a sua fiel aplicação e integral observância. A supremacia do interesse público não elimina nem neutraliza os direitos subjetivos assegurados normativamente a um particular.

108. Essa dita supremacia apenas é aplicável nas hipóteses em que inexistir uma norma legal predeterminando a solução jurídica a ser adotada. O campo próprio de aplicação da supremacia do interesse público é aquele em que não houver uma disciplina normativa específica determinando o interesse que prevalecerá. Existindo uma situação de omissão normativa específica, caberá considerar-se a supremacia do interesse público - a qual não implica, no entanto, o puro e simples sacrifício do interesse privado legítimo.

\section{VII.7.3 Solução legislativa para conflitos}

109. Por outro lado, existem hipóteses em que a própria lei determina a solução a ser adotada em vista de conflitos entre direitos subjetivos e interesses públicos e privados.

110. Em muitos casos, o ordenamento jurídico contempla as providências cabíveis para eventuais conflitos entre Administração Pública e sujeito privado. Quando assim se passa, as determinações legais são de observância obrigatória, sem qualquer margem de autonomia para a Administração Pública deixar de lhes dar aplicação.

111. O exemplo mais evidente é a desapropriação por interesse público. O direito de propriedade é protegido como um direito fundamental na $\mathrm{CF} / 88$. Admite-se a possibilidade de que um bem de domínio privado seja necessário à realização dos fins buscados pela Administração Pública. A CF/88 admite a extinção do vínculo jurídico de domínio privado, desde que observados pressupostos específicos e cumpridas exigências determinadas. Nessas hipóteses, não caberá à Administração Pública apropriar-se, de modo puro e simples, dos bens alheios mediante a invocação do "interesse público". A existência de um interesse público efetivo e consistente é um requisito necessário, mas não suficiente, para a extinção do domínio privado. Existem diversas outras exigências de observância obrigatória, que necessitam ser desenvolvidas por meio de um processo administrativo - e, em muitos casos, um processo judicial. 


\section{VIII - A disciplina da Lei 9.279}

112. A propriedade industrial é objeto de disciplina por meio da Lei Federal 9.279/1996.

\section{VIII.1 A tutela jurídica à propriedade industrial}

113. O diploma veicula regras amplas e abrangentes no tocante à proteção dos inventos.

\section{VIII.1.1 A ampla proteção à invenção}

114. O direito brasileiro promove a ampla tutela à exploração das invenções, nas suas várias manifestações. Aquelas invenções que preenchem os requisitos estabelecidos pela Lei asseguram ao seu titular, por período de tempo determinado, o direito de impedir que terceiros explorem seu objeto.

\section{VIII.1.2 A patente de invenção}

115. A patente de invenção é o instituto jurídico destinado especificamente ao invento dotado dos requisitos de patenteabilidade postos pelo artigo $8^{\circ}$ da LPI: novidade, atividade inventiva e aplicação industrial.

116. A eficácia jurídica da patente de invenção compreende a vedação à utilização da mesma invenção por um terceiro não autorizado.

\section{VIII.1.3 Os direitos assegurados ao titular da patente}

117. A patente de invenção atribui ao titular o direito de impedir a exploração, de modo direto ou indireto, do invento protegido. A própria terminologia jurídica destina-se a evidenciar uma reserva jurídica quanto à exploração, especialmente econômica.

118. O titular da patente é investido de poder jurídico para dar ao invento o destino que se lhe afigurar como o mais conveniente. Aí compreendida 
a vedação a que um terceiro, sem o consentimento do titular da patente, desenvolva qualquer atividade fundada no objeto patenteado.

119. É evidente que a patente de invenção apresenta a maior relevância no âmbito das atividades econômicas. O titular da patente é o único sujeito autorizado pela ordem jurídica a dar um destino econômico à invenção protegida. O aproveitamento da invenção por um terceiro somente será compatível com a ordem jurídica quando houver o consentimento do titular da patente.

\section{VIII.1.4 Ainda a razão de ser do privilégio patentário}

120. É relevante reiterar que a instituição do privilégio de exploração (inclusive e especialmente no plano econômico) resulta do reconhecimento da relevância social da criação promovida.

121. A criação inerente ao processo de invenção reflete a dedicação de um ou mais sujeitos ao desenvolvimento de novas soluções. Depende ainda da aplicação de recursos econômicos, os quais são usualmente muito relevantes. 122. A ausência de proteção ao invento configuraria um incentivo negativo à atividade criativa. Se um terceiro pudesse apropriar-se das ideias alheias e delas extrair os benefícios (especialmente econômicos), sem a autorização do inventor, o resultado prático seria o incentivo à atuação do chamado "freerider" ${ }^{13}$ Então, todos os esforços e toda a criatividade inerentes às atividades de criação não resultariam em benefícios para os inventores, eis que seriam apropriados por terceiros.

123. O efeito prático dessa situação seria a cessação das atividades de pesquisa, desenvolvimento e criatividade. Os inventores deixariam de aplicar o seu tempo, os seus esforços e os seus recursos econômicos nesse processo, eis que a eles não seriam assegurados benefícios diferenciados.

124. Por isso, o privilégio em favor dos titulares das patentes de invenção é reconhecido como um fator indispensável ao progresso científico e econômico.

13 A expressão "free-rider" é utilizada amplamente no campo da concorrência para indicar um sujeito que se aproveita da situação existente para auferir benefícios sem ter concorrido para a criação do cenário. $\mathrm{O}$ "free-rider" é aquele que se apropria dos benefícios propiciados pelos esforços alheios, sem se submeter aos sacrifícios e esforços indispensáveis para tanto. Por isso, um dos postulados fundamentais da repressão à concorrência desleal reside no combate às práticas de "free-rider". 
Os potenciais inovadores são incentivados a produzir soluções desconhecidas e originais mediante a garantia de que a eles será assegurada a exploração (inclusive econômica) em condições monopolistas.

\section{VIII.1.5 O privilégio temporário}

125. A patente de invenção tem prazo determinado. O privilégio da exploração econômica do invento é concedido de modo temporário. Essa temporariedade envolve duas finalidades buscadas pelo direito.

126. A fixação de um prazo delimitado permite que terceiros possam se valer da invenção, independentemente do consentimento do inventor uma vez decorrido o prazo previsto para o privilégio, e consequente entrada da invenção em domínio público.

\section{VIII.2 A repressão civil e a repressão penal}

127. A repressão jurídica à violação à patente compreende medidas de cunho penal e não penal.

\section{VIII.2.1 A tutela penal}

128. O direito configura como crime a violação aos direitos conferidos por patente de invenção. Há a tipificação penal tanto da conduta de violação direta à patente como também de outras condutas que se afiguram como pressuposto, preparação ou decorrência de tal violação.

\section{VIII.2.2 A tutela não penal}

129. Mas a violação à patente também é objeto de repressão não penal, que compreende a interdição das práticas violadoras da patente, traduzindo-se em providências de interdição de sua consumação e da submissão do infrator à obrigação de indenizar as perdas e danos decorrentes.

130. No âmbito não penal, configura-se a vedação normativa para as condutas que configurem violação à patente sob qualquer modalidade. Ou seja, a tutela 
à patente de invenção conduz à configuração de uma obrigação de não fazer. O terceiro, não titular da patente, está subordinado a uma determinação jurídica no sentido de abster-se de qualquer conduta direta ou indireta que infrinja a patente.

131. A obrigação de não fazer pode conduzir a medidas jurídicas concretas, destinadas a proporcionar-lhe eficácia plena. O Estado pode emitir provimento concreto aos potenciais infratores, inclusive para a eles determinar o pleno cumprimento às obrigações de não fazer existentes.

132. Essas considerações não excluem o cabimento da responsabilização do infrator por perdas e danos acarretadas ao titular da patente.

\section{VIII.3 As decorrências da amplitude da repressão}

133. A consagração de ampla repressão pela ordem jurídica a práticas de infração à patente é muito relevante.

\section{VIII.3.1 Ainda a distinção entre repressão penal e não penal}

134. Deve-se tomar em vista que a repressão penal apresenta características do regime correspondente. Existe uma exigência muito mais rigorosa no tocante à tipificação do ilícito e na delimitação do sancionamento.

135. Já a repressão não penal envolve uma disciplina finalística, que deve ser compreendida em vista dos fins buscados pelo ordenamento. Não seria contraditório afirmar que a finalidade principal da repressão não penal é preventiva. Ou seja, o direito aspira que os direitos compreendidos na patente de invenção sejam observados e respeitados. Por isso, são admissíveis providências destinadas a impedir a consumação da infração, segundo uma compreensão teleológica.

136. Como decorrência, a repressão não penal abarca condutas que não seriam tipificáveis como crime (nem, portanto, como tentativa), tal como traduz-se em providências concretas que impeçam a consumação de um ilícito provável. 


\section{VIII.3.2 A distinta abrangência das órbitas repressivas}

137. Dito de outro modo, a invocação da ausência de configuração de um crime não implica, de modo necessário, que a conduta seja lícita. A tutela à propriedade industrial faz-se não apenas pela repressão penal, mas também se desenvolve mediante a ampla utilização dos instrumentos não penais.

138. Nem seria necessário acrescentar que a subsunção da conduta à tipificação penal envolve, como regra, a incidência cumulativa da repressão não penal. Isso é inclusive reforçado pela redação do art. 207 da Lei 9.279:

Independentemente da ação criminal, o prejudicado poderá intentar as ações cíveis que considerar cabíveis na forma do Código de Processo Civil.

\section{VIII.4 As regras legais específicas atinentes à disciplina não penal}

139. O art. 42 da Lei 9.279 dispõe sobre os direitos do titular da patente, consagrando o regime não penal aplicável.

\section{VII.4.1 A redação do dispositivo}

140. O referido dispositivo tem a seguinte redação:

A patente confere ao seu titular o direito de impedir terceiro, sem o seu consentimento, de produzir, usar, colocar à venda, vender ou importar com estes propósitos:

I - produto objeto de patente;

II - processo ou produto obtido diretamente por processo patenteado.

$\S 1^{\circ}$ Ao titular da patente é assegurado ainda o direito de impedir que terceiros contribuam para que outros pratiquem os atos referidos neste artigo.

$\S 2^{\circ}$ Ocorrerá violação de direito da patente de processo, a que se refere o inciso II, quando o possuidor ou proprietário não comprovar, mediante determinação judicial específica, que o seu produto foi obtido por processo de fabricação diverso daquele protegido pela patente. 


\section{VIII.4.2 A violação ao uso}

141. A violação mais evidente à patente consiste no uso. Somente o titular da patente ou terceiro com o seu consentimento dispõem da faculdade de usar o invento objeto da patente (ou suas decorrências, como um medicamento que faz uso do invento).

142. A vedação legal deve ser interpretada amplamente. O verbo usar compreende toda e qualquer manifestação de aproveitamento do objeto, seja para si, seja para outrem, independentemente de proveito econômico.

\section{VIII.4.3 A proibição à conduta de produzir}

143. O dispositivo também reprime as condutas relacionadas ao uso indevido. Assim, a ilicitude atinge a produção do objeto, que se constitui em pressuposto para o uso dele. ${ }^{14}$

\section{VIII.4.4 A proibição à importação}

144. A importação pode configurar-se como um sucedâneo à conduta de produzir. Importar consiste em deslocar o objeto do estrangeiro, introduzindo-o no território nacional, sendo qualificada como ilicitude se a operação for orientada a promover uma das condutas previstas no mesmo dispositivo.

\section{VIII.4.5 A proibição à venda}

145. Também é antijurídica a conduta de vender o produto. A venda consiste na alienação do bem mediante remuneração e propicia ao infrator um proveito econômico indevido. O montante recebido na hipótese da venda configura a frustração da manifestação material da tutela jurídica.

146. É relevante insistir em que a obtenção do proveito econômico não é pressuposto da configuração da ilicitude. A Lei é clara, ao qualificar como ilícitas, condutas destituídas em si mesmas de conteúdo econômico.

14 A produção do objeto pode ser antecedida do uso de objeto idêntico, produzido em outro local. 


\section{VIII.5 A proibição à "colocação à venda"}

147. O art. 42 se refere também à conduta de colocar à venda. A relevância do tema para o presente parece justificar o aprofundamento da análise dessa solução legislativa.

\section{VIII.5.1 A solução redacional adotada}

148. A expressão "colocar à venda" não contempla o uso de termos técnico-jurídicos tradicionais. Tal opção não pode ser ignorada.

\section{VIII.5.2 Ainda a formação do contrato de venda}

149. O contrato de compra e venda aperfeiçoa-se pelo consenso de vontade entre comprador e vendedor, tendo por objeto a coisa, o preço, a quantidade e o prazo. ${ }^{15}$ Mas esse acordo de vontades é produzido mediante uma sucessão de condutas individuais, desenvolvidas de modo autônomo tanto sob o prisma psicológico como sob o ponto de vista jurídico.

\section{VIII.5.3 A oferta ou proposta}

150. O direito utiliza a expressão "oferta" ou "proposta" para indicar o ato jurídico unilateral por meio do qual um sujeito interessado em promover a compra ou a venda dirige-se a pessoa determinada ou indeterminada.

151. Por meio dessa manifestação de vontade preliminar, o sujeito indica a sua disposição em protagonizar uma contratação. Indica as condições quanto ao futuro negócio.

15 O tema é objeto de estudo da generalidade dos civilistas. Para aprofundamento, consultese Caio Mário da Silva Pereira. Instituições de direito civil, v. III - Contratos, 21. ed. 2017 e Orlando Gomes. Teoria geral dos contratos. Rio de Janeiro: Forense, 2007. 


\section{VIII.5.4 A aceitação}

152. A aceitação é o ato jurídico unilateral por meio do qual o destinatário de uma proposta de contratação exterioriza a sua concordância com as condições constantes da proposta a ele dirigida. ${ }^{16}$

\section{VIII.5.5 O aperfeiçoamento do contrato: a fusão das vontades}

153. Ocorrendo a aceitação da proposta pelo destinatário, aperfeiçoa-se o contrato e se produz a fusão das vontades. A contratação configura um negócio jurídico, caracterizado pela existência de vontades consentâneas oriundas de duas ou mais partes.

\section{VIII.5.6 A "colocação à venda"}

154. As considerações anteriores são relevantes porque a disciplina da formação do contrato não prevê formalmente a figura de "colocação à venda". Não existe um tratamento jurídico específico sobre essa prática, na disciplina geral dos contratos consagrada no Código Civil.

155. Colocar à venda consiste em conduta orientada a promover a alienação de um objeto, ainda que sem a predeterminação de condições indispensáveis para a formação do contrato. Aquele que "coloca à venda" manifesta uma vontade ampla e preliminar, refletindo a intenção de negociar algo no futuro. 156. Não pode ser ignorado que a Lei tenha evitado expressões tal como "proposta" ou "oferta", figura jurídica dotada de conteúdo técnico-jurídico determinado.

157. A solução redacional adotada pela Lei implica a repressão a conduta que não configure nem mesmo uma proposta, eis que a "colocação à venda" não depende da fixação de preço, condições de pagamento e de outras previsões essenciais a um futuro contrato.

16 Lembre-se que a "aceitação condicionada" configura uma nova proposta, em que o anterior destinatário da primeira oferta desencadeia um novo processo de contratação. Como prevê o art. 431 do Código Civil, "A aceitação fora do prazo, com adições, restrições, ou modificações, importará nova proposta". 


\section{VIII.5.7 A repressão à conduta de "colocar à venda"}

158. Para fins do art. 42 da Lei 9.279, interpreta-se amplamente a expressão "colocar à venda". O dispositivo apanha todas as condutas que materializem uma vontade, ainda que inicial, imperfeita e não completa, de promover a comercialização de um produto objeto da patente de invenção.

159. A hipótese se configura mesmo que o sujeito não indique o preço, as condições da execução da prestação, o modo e o local da produção e outras especificações essenciais à contratação.

160. Não é necessário, nem mesmo, que o produto já tenha sido fabricado ou importado. A ilicitude alcança inclusive a conduta de colocar à venda um objeto ainda inexistente, que será produzido em momento futuro - inclusive em virtude de solicitação de um terceiro cujo interesse foi despertado pela "colocação à venda".

\section{VIII.5.8 A equivalência jurídica}

161. Segundo o art. 42, merecem o mesmo tratamento jurídico as condutas de "produzir, usar, colocar à venda, vender ou importar para os referidos propósitos" do produto protegido pela patente ou do processo ou produto obtido diretamente por um processo protegido pela patente.

162. A consumação de qualquer das condutas referidas no art. 42 da Lei de Propriedade Industrial configura ilicitude, que desencadeia uma pluralidade de efeitos jurídicos.

\section{VIII.5.9 A pluralidade de direitos assegurados ao titular da patente}

163. Mas o dispositivo prevê uma consequência jurídica específica, consistente no exercício do direito de fazer cessar, de modo compulsório, a prática da infração. Isso significa que o titular da patente, diante da ocorrência das práticas referidas no dito art. 42, pode exercitar em juízo, diretamente em face do infrator, a sua pretensão de sua cessação. 


\section{VIII.5.10 A existência de dever estatal de intervir}

164. Portanto, a regra do art. 42 da Lei de Propriedade Industrial institui duas ordens de direitos para o titular da patente. Há um direito exercitável diretamente em face do infrator, mas há também um direito subjetivo em face do Estado.

165. Esse direito subjetivo não se confunde com o simples direito de ação ainda que envolva o exercício desse direito. Assim se passa porque o art. 42 cria um direito subjetivo específico em favor do titular da patente, dirigido ao Estado. Ou seja, há uma relação jurídica de direito material, por força da qual o Estado está obrigado a adotar as providências para impor a cessação de práticas que violem a patente do sujeito.

\section{VIII.5.11 A interdição à consumação da conduta contratual}

166. A interpretação sistemática implica que os direitos do titular da patente asseguram-lhe opor-se inclusive a práticas concertadas por mais de um sujeito. A preocupação legislativa apanha a conduta unilateral inclusive para evitar que uma prática contratual chegue a se consumar.

167. Assim, "colocar à venda" o produto abrangido pela proteção da patente se constitui em infração. Daí não se segue que "vender" seria lícito interpretação que atingiria as raias do despropósito. De todo modo, a Lei expressamente contempla também a conduta de "vender".

168. Anote-se que "vender" se configura como uma conduta contratual, de natureza bilateral. A operacionalização do contrato de compra e venda de objeto patenteado, sem a concordância do titular da patente, constitui uma infração. Essa infração é consumada pela conduta concomitante e conjunta do vendedor e do comprador.

\section{VIII.6 As regras legais especificas atinentes à disciplina penal}

169. A relevância dos valores protegidos por meio da patente de invenção conduziu também à tipificação penal das violações. 


\section{VIII.6.1 Os arts. 183 a 186 da Lei 9.279}

170. A Lei 9.279 veiculou a disciplina penal sobre esse tema nos arts. 183 e seguintes. Abaixo estão transcritos alguns desses dispositivos:

Art. 183. Comete crime contra patente de invenção ou de modelo de utilidade quem:

I - fabrica produto que seja objeto de patente de invenção ou de modelo de utilidade, sem autorização do titular; ou

II - usa meio ou processo que seja objeto de patente de invenção, sem autorização do titular.

Pena - detenção, de 3 (três) meses a 1 (um) ano, ou multa.

Art. 184. Comete crime contra patente de invenção ou de modelo de utilidade quem:

I - exporta, vende, expõe ou oferece à venda, tem em estoque, oculta ou recebe, para utilização com fins econômicos, produto fabricado com violação de patente de invenção ou de modelo de utilidade, ou obtido por meio ou processo patenteado; ou

II - importa produto que seja objeto de patente de invenção ou de modelo de utilidade ou obtido por meio ou processo patenteado no País, para os fins previstos no inciso anterior, e que não tenha sido colocado no mercado externo diretamente pelo titular da patente ou com seu consentimento.

Pena - detenção, de 1 (um) a 3 (três) meses, ou multa.

Art. 185. Fornecer componente de um produto patenteado, ou material ou equipamento para realizar um processo patenteado, desde que a aplicação final do componente, material ou equipamento induza, necessariamente, à exploração do objeto da patente.

Pena - detenção, de 1 (um) a 3 (três) meses, ou multa".

\section{VIII.6.2 A reiteração das considerações anteriores}

171. Em grande parte, os tipos penais indicados se reportam às práticas já referidas no art. 42. Mas a criminalização compreende outras condutas, relacionadas àquelas referidas no art. 42 . 


\section{VIII.6.3 A amplitude da repressão penal}

172. A transcrição acima realizada dos dispositivos penais destinou-se a evidenciar a amplitude da repressão consagrada. Mais do que isso, é indispensável apontar a dimensão simbólica desse tratamento.

173. Foram tipificadas condutas de diversa natureza, que se relacionam com a violação aos direitos inerentes à patente outorgada. A lei foi minuciosa, inclusive para evitar incertezas quanto à antijuridicidade das práticas.

174. Para exemplificar, considere-se o art. 184. Configura crime não apenas a venda. Também é penalmente reprovável a oferta à venda e a simples exposição. Mais ainda, basta o sujeito ter em estoque um produto. Como se não bastasse, a ocultação do produto é igualmente tipificada como crime. Ainda além, o recebimento de produto fabricado com violação a patente consuma crime se o recebimento envolver uma destinação ulterior com fim econômico. 175. O rigor do tratamento legislativo conduziu também à tipificação autônoma de condutas indispensáveis à consumação do crime. $\mathrm{O}$ mero fornecimento de um componente ou de material ou equipamento necessário à produção se constituem em crime, se tais condutas induzirem necessariamente à exploração indevida de um objeto patenteado.

\section{VIII.6.4 Ainda a amplitude da repressão penal}

176. É relevante insistir em que a Lei tipifica como crime autônomo as diversas categorias de condutas. Não se trata de penalizar apenas a "venda" e considerar que manter o bem em estoque configuraria uma "tentativa". A própria oferta de venda do produto objeto da patente configura-se como crime consumado.

\section{VIII.6.5 Crimes de perigo ou formais}

177. Não seria incorreto, então, reconhecer a existência de crimes de perigo ou formais. Como se sabe, essa categoria compreende condutas que a lei penal reputa como tão graves que exigem repressão independentemente da efetiva consumação de um dano material ou patrimonial.

178. Assim se passa no tocante à violação a patentes de invenção. 


\section{VIII.7 Sintese}

179. A análise desenvolvida destinou-se a evidenciar que o direito brasileiro consagrou proteção efetiva, séria e severa em favor dos titulares de patentes de invenção. A disciplina legislativa foi concebida de modo a eliminar subterfúgios ou sutilezas, que permitissem a impunidade ao sujeito violador dos valores protegidos.

\section{IX - A figura do contrato administrativo}

180. A expressão "contrato administrativo" compreende uma pluralidade de figuras dotadas de características diversas. ${ }^{17}$

\section{IX.1 A acepção ampla}

181. Em acepção ampla, contrato administrativo compreende todo acordo de vontades, destinado a disciplinar a conduta posterior das partes, de que participa a Administração Pública. Sob esse enfoque, o conceito de contrato administrativo compreende uma grande gama de figuras jurídicas.

\section{IX.2 As espécies de contratos administrativos}

182. Em termos de sistematização, o signatário tem diferenciado três espécies compreendidas no gênero "contrato administrativo em sentido amplo". Há os contratos de direito privado da Administração Pública, os contratos administrativos em sentido restrito e os acordos de vontade da Administração.

17 Esse entendimento é compartilhado pela generalidade da doutrina. Para uma análise mais detida, consulte-se Marçal Justen Filho. Comentários à Lei de Licitações e Contratos Administrativos. 17. ed. São Paulo: RT, 2016. p. 1073 e ss. 


\section{IX.2.1 Os contratos de direito privado da Administração Pública}

183. A Administração pode participar de contratos típicos do direito privado, cujo regime jurídico não é afetado de modo significativo em tais hipóteses. Assim, por exemplo, considere-se um contrato de seguro em que a Administração assume a condição de segurado. Esses são os contratos de direito privado da Administração Pública, referidos no art. 62, §3º , inc. I, da Lei $8.666 .^{18}$

\section{IX.2.2 Os contratos administrativos em sentido restrito}

184. Há contratos administrativos em sentido próprio ou restrito, que se caracterizam por um regime jurídico diferenciado. A Administração é investida de competências anômalas ("prerrogativas extraordinárias"), que compreendem, por exemplo, poderes para alterar unilateralmente o conteúdo do contrato. Essa figura comporta duas subespécies. Há os contratos de colaboração (compra, alienação, serviços, inclusive de obras públicas), regidos pela Lei 8.666. E também existem os contratos de delegação (permissão e concessão de serviço público), disciplinados por leis setoriais - ainda que normas gerais sobre o tema tenham sido veiculadas pela Lei 8.987/1995.

\section{IX.2.3 Os acordos de vontade da Administração Pública}

185. O terceiro grupo - acordos de vontade da Administração Pública é composto por figuras diversas, com objeto e regime jurídico variado. Essa categoria compreende, por exemplo, os convênios públicos.

\section{IX.3 A distinção entre convênio e contrato administrativo restrito}

186. Para os fins do presente parecer, é relevante acentuar a distinção entre convênio e contrato administrativo em sentido restrito.

18 "Aplica-se o disposto nos arts. 55 e 58 a 61 desta Lei e demais normas gerais, no que couber: I - aos contratos de seguro, de financiamento, de locação em que o Poder Público seja locatário, e aos demais cujo conteúdo seja regido, predominantemente, por norma de direito privado; ..." 


\section{IX.3.1 O fim comum destituído de interesse econômico}

187. O convênio público se caracteriza pela participação de dois ou mais sujeitos, sendo pelo menos um deles integrante da Administração Pública, que se obrigam a conjugar esforços e recursos, sem interesse próprio de natureza econômica.

188. No convênio, nenhuma das partes é investida da faculdade jurídica de incorporar em seu patrimônio o produto da prestação executada pela outra. Não existe a comutatividade própria dos contratos ditos "de escambo", que são aqueles em que a prestação executada pela parte passa a integrar o patrimônio da outra.

189. A finalidade do convênio é produzir benefícios e vantagens para a coletividade ou para terceiros, que não sejam parte no contrato. Por isso, os participantes do convênio atuam de modo desinteressado, visando o bem alheio.

\section{IX.3.2 O contrato administrativo em sentido restrito}

190. Já o contrato administrativo em sentido restrito, especialmente aquele de colaboração, caracteriza-se pelo interesse econômico das partes. A Administração obriga-se a realizar uma prestação, cujo objeto reverterá para o patrimônio do particular. E, de modo recíproco, a prestação a ser executada pelo particular será integrada ao domínio da Administração Pública.

\section{IX.3.3 A irrelevância da denominação}

191. Evidentemente, a denominação adotada na Lei, Regulamento ou ato concreto não afeta a natureza e o regime jurídico aplicável. É imperioso examinar as normas consensualmente adotadas entre as partes e os demais atributos e finalidades da avença.

192. Por isso, é perfeitamente possível que uma avença seja denominada de "convênio", sem preencher os requisitos correspondentes. Suponha-se, por exemplo, um acordo de vontades prevendo a obrigação de um particular a realizar prestação de interesse da Administração, a qual se obriga a promover pagamento em contrapartida. Nesse caso, não existe um convênio, mas há um contrato administrativo em sentido restrito. 


\section{X - As Parcerias para o Desenvolvimento Produtivo (PDP)}

193. Os pressupostos acima expostos são relevantes para a avaliação do caso concreto, que envolve práticas desenvolvidas no âmbito de programa governamental de transferência de tecnologia associada com o fornecimento de medicamentos. Conforme se detalhará abaixo, apesar do nome "parceria", as PDPs não são um convênio, mas sim um contrato administrativo.

\section{X.1 A Lei 10.973/2004}

194. A Lei 10.973/2004 contemplou uma pluralidade de medidas destinadas a incentivar a inovação e a pesquisa científica e tecnológica. O diploma autorizou a aplicação de recursos públicos para atividades de inovação e de exploração de inventos e descobertas.

\section{X.1.1 A figura da ICT}

195. Esses acordos de parcerias podem contemplar uma pluralidade de arranjos negociais. Assim, por exemplo, admite-se a aplicação de recursos públicos para execução de projeto de pesquisa a ser desenvolvido por ICT (art. 9-A). A ICT pode obter o direito de uso ou de exploração de criação protegida (art. $7^{\circ}$ ). A ICT pública pode celebrar contrato para transferência de tecnologia tal como para a exploração da criação por ela desenvolvida (art. $6^{\circ}$ ).

\section{X.1.2 A autorização para parcerias para promover inovações}

196. Entre as alternativas consagradas, foi prevista a solução da parceria. O art. 9 fixou o seguinte:

É facultado à ICT celebrar acordos de parceria com instituições públicas e privadas para realização de atividades conjuntas de pesquisa científica e tecnológica e de desenvolvimento de tecnologia, produto, serviço ou processo. ${ }^{19}$

19 A expressão "ICT" significa "Instituição Científica, Tecnológica e de Inovação", qualificação que pode ser reconhecida a órgão ou entidade da Administração Pública ou pessoa jurídica de direito privado sem fins lucrativos. 


\section{X.2 A figura das Parcerias para o Desenvolvimento Produtivo (PDP)}

197. A Administração Pública federal editou, ao longo do tempo, diversos normativos infralegais para dispor sobre instrumentos jurídicos para formalizar associações relacionadas com a inovação tecnológica e científica. Entre as soluções concebidas, encontrava-se a Parceria para o Desenvolvimento Produtivo.

198. Basicamente, a finalidade buscada pela PDP é a transferência de tecnologia para a capacitação das instituições públicas para atendimento as necessidades do SUS.

\section{X.2.1 A disciplina infralegal - as Portarias 837/2012 e 2.531/2014}

199. A Portaria 837/2012, do Ministério da Saúde, estabeleceu os critérios para o estabelecimento de PDP. Posteriormente, foi editada a Portaria 2.531/2014, também do Ministério da Saúde. No seu art. 2º, inc. I, consta a seguinte definição:

Parceria para o Desenvolvimento Produtivo (PDP): parcerias que envolvem a cooperação mediante acordo entre instituições públicas e entre instituições públicas e entidades privadas para desenvolvimento, transferência e absorção de tecnologia, produção, capacitação produtiva e tecnológica do País em produtos estratégicos para atendimento às demandas do SUS.

200. Segundo o inc. V do art. $2^{\circ}$, instituição pública consiste em:

órgão ou entidade da Administração Pública, Direta ou Indireta, de uma das três esferas do governo, que atue em pesquisa, desenvolvimento ou produção de medicamentos, soros, vacinas ou produtos para a saúde; ;..

201. O inc. VI do mesmo art. $2^{\circ}$ também dispõe sobre a entidade privada, nos termos seguintes:

entidade privada: pessoa jurídica de direito privado, não integrante da Administração Pública, Direta ou Indireta, que seja detentora, desenvolvedora, possua licença da tecnologia a ser transferida ou que seja responsável pela produção de uma etapa da cadeia produtiva no País. 


\section{X.2.2 A disciplina infralegal inaplicável - o Dec. 9.245/2017}

202. Apenas por cautela, cabe destacar que não se aplica no caso concreto o Decreto Federal 9.245, de 20.12.2017, que instituiu a Política Nacional de Inovação Tecnológica na Saúde - PNITS. Segundo o art. 20 do referido diploma (com a redação adotada pelo Dec. 9.307, de 15.3.2018):

O disposto neste Decreto não se aplica:

I - aos processos administrativos de PDP, ETECS e MECS instaurados até 20 de dezembro de 2017, independentemente da fase em que se encontrem; e II - aos instrumentos relacionados a PDP, ETECS e MECS vigentes em 21 de dezembro de 2017, exceto se for possível adequá-los de forma a torná-los compatíveis com o disposto neste Decreto, sem acarretar prejuízo ao erário, e houver manifestação expressa de interesse das partes envolvidas.

203. A contratação examinada no caso concreto já se encontrava em curso de formalização em 20.12.2017. Portanto, a disciplina aplicável é aquela acima referida (Portaria 2.531/2014), vigente à época da ocorrência dos eventos juridicamente relevantes.

\section{X.3 A ausência de surgimento de nova pessoa jurídica}

204. A Parceria para o Desenvolvimento Produtivo envolve uma associação temporária e delimitada de esforços entre entes administrativos estatais e empresas privadas.

\section{X.3.1 A ausência da criação de uma estrutura jurídica autônoma}

205. A associação inerente à PDP não produz o surgimento de uma pessoa jurídica autônoma, dotada de existência própria e destinada à realização de fins específicos. 


\section{X.3.2 A existência de relacionamento puramente contratual}

206. Isso significa que os "parceiros" estabelecem um relacionamento jurídico de natureza contratual. Assumem direitos e obrigações reciprocamente, que serão executados em nome próprio.

\section{X.4 A natureza complexa do relacionamento jurídico}

207. É relevante assinalar que a figura da PDP apresenta natureza jurídica complexa, eis que envolve duas figuras contratuais distintas, ainda que entre si indissociavelmente relacionadas.

\section{X.4.1 A finalidade da parceria e os meios para sua consecução}

208. A parceria vincula instituições públicas ou instituições públicas e instituições privadas, visando um conjunto de prestações de natureza heterogênea. A finalidade última é assegurar a produção no Brasil de medicamentos reputados como estratégicos ao SUS, a quem serão eles fornecidos.

209. Para atingir esse fim, as partes pactuam obrigações recíprocas orientadas a promover o desenvolvimento, transferência e absorção de tecnologia, tal como a produção, capacitação produtiva e tecnológica no País.

\section{X.4.2 A impossibilidade de dissociação das etapas}

210. Existem etapas jurídicas diversas na PDP, mas nenhuma delas é dotada de autonomia própria. Ou seja, nenhuma das etapas se justifica em si mesma. Por isso, o atingimento da finalidade específica de cada etapa não configura o sucesso da PDP.

211. A PDP somente atinge as suas finalidades quando todas as etapas previstas são executadas e é atingido o resultado final. 


\section{X.5 A pluralidade de etapas jurídicas}

212. A execução da PDP se faz mediante a conjugação de uma pluralidade de atos jurídicos, que se desenvolvem de modo interconectado, mediante um procedimento contínuo.

\section{X.5.1 A etapa de transferência de tecnologia e capacitação produtiva}

213. Existe uma atuação orientada à transferência de tecnologia e capacitação produtiva. Nesse cenário, há um sujeito que é titular da tecnologia (e que deve ser também o titular da patente de invenção pertinente, quando existente) pertinente ao medicamento qualificado como estratégico. Essa tecnologia será transferida para uma instituição pública brasileira, mediante um processo orientado a dotá-la da capacitação para produzir o referido medicamento no País.

\section{X.5.2 A etapa de fornecimento do medicamento para o SUS}

214. Em momento posterior, ocorrerá a venda do medicamento pela entidade privada para instituição pública para fornecimento ao SUS. A relevância estratégica do referido medicamento relaciona-se com a necessidade de fornecimentos reiterados e contínuos no âmbito do SUS, como também para compensar financeiramente a entidade privada pela transferência da tecnologia.

215. Portanto, há a previsão de uma sucessão de operações de compra e venda ao longo do tempo durante a vigência da PDP. Após o seu término e sendo bem-sucedida a transferência da tecnologia - ou seja, estando a instituição pública capacitada para produção do produto -, haverá negociação entre a instituição pública e o Ministério da Saúde para o abastecimento contínuo do SUS. 


\section{X.5.3 Ainda o vínculo jurídico formal entre as etapas}

216. O vínculo formal entre as duas etapas decorre de que existe um único negócio jurídico abrangente. As duas etapas não consistem em operações dissociadas entre si. Não há um contrato de cessão de tecnologia independente de um (ou mais) contrato(s) de compra e venda de medicamentos.

217. Existe uma proposta única para a negociação. No momento inicial, o negócio jurídico compreende não apenas a cessão da tecnologia e a capacitação para a produção do medicamento, mas também a obrigação de compra do medicamento em face da empresa privada para abastecimento do SUS.

218. Assim, a cessão da tecnologia e a capacitação para a produção do medicamento são instrumentais à concretização dos objetivos da PDP e à implementação da compra e venda para abastecimento do SUS, após o término da PDP.

\section{X.5.4 A garantia de compra e a redução de custos de transação}

219. Ou seja, a garantia da compra do medicamento em face da entidade privada durante a vigência da PDP se constitui num aspecto econômico fundamental para a viabilização do empreendimento. A certeza quanto à obtenção de receitas reduz os chamados "custos de transação" do empreendimento e assegura à entidade privada a remuneração pela transferência da tecnologia.

\section{X.5.5 A solução formal do Dec. 9.245}

220. Embora o Dec. 9.245 seja inaplicável ao caso, é interessante observar que o referido diploma adotou uma solução jurídica que traduz o enfoque acima exposto. O seu art. $8^{\circ}$ determinou o seguinte:

A formalização da PDP ocorre mediante a assinatura de contrato entre as três partes envolvidas, quais sejam:

I - o Ministério da Saúde;

II - o parceiro público - o órgão ou a entidade públicos ou a empresa estatal, isoladamente ou em consórcio com outro parceiro público; $e$

III - o parceiro privado - a entidade privada, isoladamente ou em consórcio com outro parceiro privado. 
221. Ou seja, o Dec. 9.245 reconhece que a PDP produz uma relação jurídica entre três partes distintas, compreendendo obrigações de distinta natureza entre elas - mas gerando um único vínculo jurídico indissociável.

\section{X.6 A remuneração assegurada à entidade privada}

222. Para os fins do presente parecer, interessa considerar as hipóteses de transferência da tecnologia de titularidade de uma entidade privada em favor de uma instituição pública, acompanhada da capacitação desta para a produção do medicamento.

\section{X.6.1 A titularidade de direitos e conhecimentos por entidade privada}

223. Nessa hipótese, há uma entidade privada titular de direitos e conhecimentos indispensáveis ao atingimento da finalidade buscada pela Administração Pública brasileira.

\section{X.6.2 As obrigações de fazer impostas à entidade privada}

224. Por meio da PDP, a entidade privada se obriga a executar uma pluralidade de prestações, que compreendem obrigações de fazer. Isso envolve a cessão da tecnologia, a qualificação do pessoal da instituição pública para o seu manejo, a eventual especificação de equipamentos, o desenvolvimento de controle de qualidade e diversas outras prestações de conteúdo variável em vista das circunstâncias.

\section{X.6.3 A remuneração da entidade privada}

225. Evidentemente, a entidade privada não desempenha uma atividade desinteressada. Trata-se de uma atuação empresarial, em que todas as obrigações são assumidas em vista de uma contrapartida financeira. 
226. O Estado brasileiro remunera a entidade privada, mediante o pagamento do preço na compra do produto objeto da PDP, a fim de compensar a execução das obrigações assumidas.

\section{X.6.4 O preço recebido pela entidade privada}

227. A remuneração à entidade privada é obtida mediante o preço desembolsado pela instituição pública (indiretamente pelo SUS). Esse preço remunera não apenas o fornecimento do produto adquirido, mas também a transferência da tecnologia e todas as demais obrigações de fazer assumidas pela entidade privada.

\section{X.6.5 As diversas compras e vendas}

228. No âmbito da PDP, existe uma pluralidade de operações de compra e venda, entre sujeitos diversos.

229. Em princípio, a entidade privada não realiza vendas diretamente para o SUS. Essas operações de fornecimento são realizadas para a instituição pública. Na sequência, há a venda da instituição pública para o SUS.

\section{X.7 A inexistência de um convênio}

230. A hipótese não configura um convênio, precisamente porque existe um interesse econômico próprio da entidade privada que fornece a tecnologia e propicia a capacitação produtiva para a fabricação do medicamento no País pela instituição pública.

\section{X.7.1 A questão do preço}

231. Como indicado, o contrato destina-se a assegurar o fornecimento de medicamentos para o SUS, o que envolve operações de compra e venda, tal como previsto no art. 55 da Portaria 2.531, abaixo reproduzido: 
A aquisição do produto objeto da PDP se dará entre o Ministério da Saúde e a instituição pública, por meio de instrumento específico, e será realizada após observância e reanálise dos seguintes itens: ...

232. Ou seja, a entidade privada que participar da PDP obterá uma remuneração, que será incorporada ao seu patrimônio, como contrapartida das diversas prestações executadas.

\section{X.7.2 A amplitude do preço}

233. Anote-se que esse preço destina-se não apenas a remunerar a venda propriamente dita do medicamento, mas também a compensar a transferência da tecnologia pertinente. Ou seja, o "custo" pago pelo SUS referente ao medicamento comprado da instituição pública compreende não apenas as despesas necessárias à produção material do medicamento e a margem de lucro imposta sobre o preço, mas também uma remuneração pela tecnologia transferida.

234. Justamente por isso, o referido art. 55, inc. III, determina o seguinte:

a) os preços estabelecidos para a aquisição de produto objeto da PDP considerarão o aporte tecnológico associado à internalização da produção...

\section{X.7.3 A irrelevância da expressão "Parceria"}

235. Apenas por cautela, é irrelevante a utilização da expressão "parceria". Tal como já exposto, a denominação atribuída ao ato jurídico não determina a sua natureza jurídica.

236. Por outro lado, a própria legislação brasileira já se valeu da expressão "Parceria Público-Privada" (Lei 11.079/2004) para aludir a um contrato administrativo em sentido restrito, consistente numa modalidade de concessão de serviço público. 


\section{X.8 A existência de um contrato administrativo}

237. A PDP configura um contrato administrativo em sentido restrito ou próprio, ainda que dotado de peculiaridades próprias.

\section{X.8.1 A presença das competências anômalas}

238. Na PDP, a Administração Pública é investida das competências anômalas previstas no art. 58 da Lei 8.666. Ainda que a contratação não seja regida de modo integral pelo referido diploma, são reconhecidos à Administração Pública os poderes jurídicos diferenciados, tais como a alteração do objeto, o sancionamento do particular e a extinção por decisão unilateral.

\section{X.8.2 A observância do regime jurídico de direito privado}

239. Como é evidente, no entanto, a contratação de PDP não afasta a incidência das normas jurídicas pertinentes à exploração empresarial. A instauração da parceria, que compreende inclusive a cessão de tecnologia, pressupõe a observância das normas que dispõem sobre esse tema, tal como adiante será mais bem exposto.

\section{XI - O problema da contratação direta}

240. Os produtos objeto da PDP serão objeto de fornecimento à Administração Pública, mediante contratação direta. Esses produtos serão fornecidos pela instituição pública, embora anteriormente adquiridos junto à entidade privada.

\section{XX.1 A solução da contratação direta}

241. Os incs. XXXI, XXXII e XXXIV do art. 24 Lei 8.666 dispõem sobre a dispensa de licitação para contratações relacionadas com as atividades de pesquisa científica e tecnológica referidas na Lei 10.973. 
242. Lembre-se, no entanto, que o art. 25, inc. I, da mesma Lei 8.666 reconhece que a existência de patente de invenção conduz não à dispensa de licitação, mas à sua inexigibilidade.

\section{XI.2 Os limites da discricionariedade administrativa}

243. A autorização legislativa para a contratação direta não significa, no entanto, a autonomia da autoridade estatal para adotar livremente uma solução, fundada em razões puramente subjetivas e sem a observância de requisitos procedimentais determinados.

\section{XI.2.1 A questão do procedimento prévio}

244. Qualquer contratação é antecedida de um procedimento prévio, por meio do qual as partes exteriorizam os seus interesses e atingem um consenso quanto à formação do contrato.

\section{XI.2.2 O procedimento administrativo prévio obrigatório}

245. No âmbito da iniciativa privada, o procedimento pré-contratual não é usualmente objeto de disciplina normativa. Diversamente se passa no tocante à atividade administrativa.

246. A contratação administrativa deve obrigatoriamente ser precedida de uma pluralidade de atos jurídicos preliminares, dotados de um grau relevante de formalismo. Essa afirmativa prevalece inclusive nas hipóteses de contratação direta, sem licitação.

247. Toda e qualquer contratação administrativa compreende uma etapa preliminar, em que a Administração identifica as próprias necessidades, cogita das soluções disponíveis e verifica as propostas mais vantajosas de contratação. Quanto a isso, não há distinção entre contratação administrativa precedida e não precedida de licitação. A variação entre as duas hipóteses relaciona-se com o formalismo do procedimento a ser observado. ${ }^{20}$

20 Não é casual, por isso, que o signatário tenha afirmado que a contratação direta não deixa de ser um procedimento licitatório. Essa afirmativa, que parece ser incorreta, reflete o 


\section{XI.2.3 O procedimento prévio e o convite à formulação de propostas}

248. O procedimento prévio antecedente à contratação administrativa compreende uma etapa de convite aos interessados para formular propostas. $\mathrm{Ou}$ seja, a Administração Pública não formula propostas para os potenciais contratantes. ${ }^{21}$ A licitação se constitui em uma invitatio ad oferendum.

\section{XI.3 Ainda a formulação de propostas para projetos de PDP}

249. A contratação de PDP envolve um procedimento seletivo prévio, sendo incabível promover uma licitação típica da Lei 8.666. ${ }^{22}$ Mas isso não afasta, pelos motivos já expostos, a observância de um procedimento pré-contratual determinado.

\section{XI.3.1 A exigência de procedimento preliminar para a PDP}

250. A Portaria 2.531/2014 disciplinou de modo bastante minucioso o procedimento prévio a contratação de PDP. Esse procedimento consagra a solução tradicional do recebimento pela Administração Pública de uma proposta de contratação.

reconhecimento de que as hipóteses de dispensa e de inexigibilidade de licitação não afastam a obrigatoriedade do cumprimento das diversas etapas necessárias à adoção de solução compatível com a ordem jurídica. Sobre o tema, confira-se Comentários à lei de licitações e contratos administrativos. 17. ed. São Paulo: Revista dos Tribunais, 2016. p. 466 e ss.

21 Pode-se presumir que essa disciplina relacionou-se com a concepção de que a proposta vincula o proponente e que a sua aceitação acarreta o aperfeiçoamento do contrato. Deve-se ter em vista a tradicional concepção de que a Administração se reserva o direito de não contratar, não obstante exaurido o procedimento prévio. Essa concepção tem sido objeto de sérias críticas, inclusive do signatário. De todo modo, consolidou-se o entendimento de que a Administração nunca formula proposta. Quando muito, manifesta o seu interesse em contratar e convoca possíveis interessados para que formulem as suas propostas.

22 Não cabe, nesse ponto, aprofundar as razões do descabimento de licitação para contratação de parcerias. Algumas considerações do pensamento do autor podem ser encontradas em "A contratação sem licitação nas empresas estatais". In: Marçal Justen Filho (Org.). Estatuto jurídico das empresas estatais. Lei 13.303/2016 - Lei das Estatais. São Paulo: RT, 2016. p. 283-352. 


\section{XI.3.2 As regras do Dec. 9.245}

251. Embora o Dec. 9.245 não seja aplicável ao caso, dele consta uma regra inerente à atividade contratual desenvolvida pelo Estado brasileiro. Ali foi previsto, formalmente, o seguinte:

Art. 9 $A$ seleção do parceiro privado a ser contratado pela administração pública, no âmbito da PDP, será feita por meio de procedimentos objetivos, transparentes e simplificados, definidos em ato do Ministro de Estado da Saúde, após ouvido o Gecis.

252. Essa regra é uma decorrência do regime jurídico de direito administrativo, que exige a impessoalidade e a motivação, tal como a publicidade das decisões adotadas.

\section{XI.4 A "Proposta de Projeto de PDP" e a sua natureza jurídica}

253. O regulamento alude a uma "proposta de projeto de PDP", que deve observar uma série de requisitos, de modo a permitir uma avaliação de conveniência e vantajosidade para a Administração Federal.

\section{XI.4.1 A terminologia adotada}

254. Não é casual a utilização da expressão "proposta". Trata-se de adotar a orientação de que a Administração adota uma posição de destinatária de uma manifestação de vontade alheia. Essa manifestação de vontade versa sobre uma potencial contratação.

\section{XI.4.2 As peculiaridades da Proposta de Projeto de PDP}

255. A Proposta de Projeto de PDP compreende também a especificação da proposta de contratação futura.

256. Deve-se ter em mente que o modelo adotado envolve não apenas a transferência de tecnologia propriamente dita, mas também, e principalmente, o 
fornecimento do medicamento a ser executado durante a vigência do contrato administrativo. Logo, existem propostas relativas a essas duas questões.

257. Isso pode ser melhor compreendido mediante uma breve referência ao art. 14 da referida Portaria, que estabelece os requisitos a serem observados na elaboração da proposta de projeto. Ali está previsto, por exemplo, que a proposta deve conter:

VII - quanto ao processo de produção:

a) o projeto deve proporcionar o desenvolvimento do CEIS e apresentar as condições para tornar a instituição pública apta a produzir o produto objeto da PDP;

b) deverá ser apresentado o fluxo de produção planejado detalhadamente, envolvendo-se, no que se refere à infraestrutura:

1. a estrutura física necessária, com indicação se as plantas produtivas dos parceiros envolvidos possuem projetos de investimento;

2. as condições apropriadas para execução do projeto, englobando-se instalações, procedimentos, processos e recursos organizacionais; $e$

3. quando necessárias adequações na infraestrutura, serão especificados pela instituição pública, no projeto executivo, os recursos necessários, os valores orçados e a previsão de conclusão dos investimentos críticos para a viabilização da PDP por parte de todos os parceiros; ...

258. Em outro inciso, consta a exigência de que:

VIII - quanto à proposta de preço de venda e estimativa da capacidade de oferta:

a) serão apresentadas propostas com os valores unitários anuais em termos nominais e a capacidade de oferta anual do produ to para o período do projeto; ...

259. Por isso, o "Projeto de Proposta" contempla não apenas uma proposta quanto às condições da parceria propriamente dita, mas também relativamente às contratações relativas ao fornecimento do medicamento durante a vigência do contrato. 


\section{XI.4.3 A proposta única e os efeitos jurídicos decorrentes}

260. A proposta de PDP contempla, de modo abrangente, não apenas o tema da transferência de tecnologia e capacitação para a produção do medicamento. Também engloba as condições do fornecimento.

261. Isso decorre de que a PDP compreende não apenas a obrigação de fazer, mas também a obrigação de dar. Portanto, a entidade privada que participa da proposta de PDP oferece à Administração Pública a venda do referido medicamento, com a obrigação de fornecê-lo nas condições predeterminadas.

\section{XX.4.4 A aceitação da proposta e a obrigação de comprar}

262. Daí se segue que a aceitação da proposta de PDP produz uma obrigação essencial e nuclear para a Administração Pública: comprar o medicamento objeto do negócio.

263. Ao aceitar a proposta da PDP, a Administração Pública obriga-se a comprar o medicamento, nas condições estabelecidas. Todas as condições necessárias ao aperfeiçoamento do negócio estão presentes.

\section{XI.5 A óbvia exigência de respeito à propriedade intelectual}

264. É evidente que nenhuma PDP pode ser implementada visando promover a violação às leis de propriedade industrial. Voltar-se-á ao tema adiante.

XX.5.1 A previsão do art. 14, inc. III

265. É cabível ressaltar que o art. 14 da Portaria refere-se reiteradas vezes à exigência de titularidade pela entidade privada dos direitos de propriedade industrial relacionados ao objeto da contratação. $\mathrm{O}$ dispositivo tem a seguinte redação:

A elaboração de proposta de projeto de PDP observará as seguintes diretrizes:

III - quanto à propriedade intelectual: 
a) a pesquisa, o desenvolvimento e a fabricação dos produtos a serem adquiridos no âmbito da PDP seguirão a legislação vigente; ...

b) a entidade privada detentora ou desenvolvedora da tecnologia do produto, que será responsável pela transferência da tecnologia à instituição pública.

\section{XX.5.2 A exigência expressa do art. 22, inc. VIII}

266. A exigência de respeito a direitos de titulares de patente é expressamente reconhecida no art. 22, inc. VIII, da Portaria, abaixo transcrito:

Serão considerados na análise de mérito da proposta de projeto de PDP os seguintes critérios:

VIII - observância da legislação de propriedade intelectual em vigor; ...

267. Portanto, é vedada a aprovação de uma PDP que implique violação a patentes de invenção.

\section{XI.6 A questão da vantajosidade}

268. As considerações anteriores evidenciam que um dos temas centrais relacionados com as PDPs consiste na vantajosidade econômica.

\section{XI.6.1 O modelo contratual e a ausência de licitação para as compras}

269. A modelagem contratual não diferencia a remuneração pela tecnologia e o pagamento pelo produto propriamente dito. Isso dá oportunidade a negócios jurídicos com preço mais elevado do que poderia ser obtido no mercado. 270. Esse risco é incrementado pela existência de um procedimento simplificado de seleção dos potenciais interessados em participar da PDP e pela dispensa de licitação para a compra dos medicamentos a serem futuramente fabricados. 


\section{XI.6.2 A exigência constitucional de absoluta transparência}

271. Os problemas acima apontados exigem, por isso, a absoluta transparência dos processos de contratação de PDPs. A invocação genérica ao "interesse público" e a exigência de fomento à inovação tecnológica não podem impedir a avaliação concreta e efetiva da vantajosidade das contratações realizadas. 272. Ou seja, não se admite a tentativa delegitimação de práticas administrativas mediante a invocação a princípios genéricos e abstratos, sem a comprovação efetiva do atendimento aos valores norteadores da atividade administrativa.

\section{XII — Ainda a Lei de Acesso à Informação}

273. Existe uma determinação constitucional geral e ampla, consistente na transparência da atividade administrativa estatal. Essa é uma regra geral que apenas pode ser restringida em situações excepcionais, tal como regulamentado pela Lei de Acesso à Informação (Lei Federal 12.527/2011).

\section{XII.7 Ainda as diversas funções da publicidade}

274. É fundamental assinalar que a publicidade da atividade administrativa do Estado é orientada a promover diversos fins protegidos constitucionalmente.

\section{XII.1.1 As funções da publicidade}

275. O objetivo mais evidente é permitir o conhecimento de todos os interessados, nacionais e estrangeiros, quanto ao conteúdo dos atos administrativos praticados pelo Estado.

276. Mas a publicidade também apresenta uma função preventiva de grande relevo. A obrigatoriedade da divulgação dos atos administrativos e dos processos administrativos em que eles são praticados - ou seja, a antevisão de que todos os atos praticados serão levados ao conhecimento público constitui-se em importante providência de desincentivo a práticas irregulares. A perspectiva da revelação das ilicitudes eleva a probabilidade quanto ao sancionamento do infrator. Por isso, a exigência de publicidade é uma providência muito relevante para assegurar a regularidade da atividade estatal. 


\section{XII.1.2 O direito fundamental à informação}

277. $\mathrm{O}$ art. 37 da $\mathrm{CF} / 88$ determinou que " $A$ administração pública direta e indireta de qualquer dos Poderes da União, dos Estados, do Distrito Federal e dos Municípios obedecerá aos princípios de legalidade, impessoalidade, moralidade, publicidade e eficiência ...".

278. $\mathrm{O}$ art. 5o, inc. XIV, da $\mathrm{CF} / 88$ determinou que o acesso à informação se constitui em direito fundamental de todos os cidadãos. E o inc. XXXIII do mesmo art. $5^{\circ}$ previu que:

todos têm direito a receber dos órgãos públicos informações de seu interesse particular, ou de interesse coletivo ou geral, que serão prestadas no prazo da lei, sob pena de responsabilidade, ressalvadas aquelas cujo sigilo seja imprescindível à segurança da sociedade e do Estado;

279. Observe-se que esse direito fundamental abrange não apenas o interesse particular do cidadão, mas também aquelas informações de interesse "coletivo ou geral".

\section{XII.1.3 As hipóteses legais de restrição à publicidade}

280. A publicidade apenas será restringida como exceção. Assim se passará nas hipóteses em que a revelação dos eventos verificados no âmbito da Administração Pública for potencialmente apta a colocar em risco valores protegidos pela ordem jurídica. A Lei de Acesso à Informação admite a restrição à divulgação de informações, mas sempre como exceção.

\section{XII.2 A Lei $4.717 / 1965$}

281. O art. $1^{\underline{o}}$ da Lei da Ação Popular (Lei 4.717) determinou o seguinte:

$\$ 4^{\circ}$ Para instruir a inicial, o cidadão poderá requerer às entidades, a que se refere este artigo, as certidões e informações que julgar necessárias, bastando para isso indicar a finalidade das mesmas. 
$\S 5^{\circ}$ As certidões e informações, a que se refere o parágrafo anterior, deverão ser fornecidas dentro de 15 (quinze) dias da entrega, sob recibo, dos respectivos requerimentos, e só poderão ser utilizadas para a instrução de ação popular.

$\S 6^{0}$ Somente nos casos em que o interesse público, devidamente justificado, impuser sigilo, poderá ser negada certidão ou informação.

$\S 7^{0}$ Ocorrendo a hipótese do parágrafo anterior, a ação poderá ser proposta desacompanhada das certidões ou informações negadas, cabendo ao juiz, após apreciar os motivos do indeferimento, e salvo em se tratando de razão de segurança nacional, requisitar umas e outras; feita a requisição, o processo correrá em segredo de justiça, que cessará com o trânsito em julgado de sentença condenatória.

282. Ou seja, o argumento do interesse público quanto ao sigilo da informação não é oponível ao interesse público na preservação da regularidade dos atos administrativos.

283. Mesmo nas hipóteses em que o contrato administrativo versar sobre questões de segurança nacional, incidirão os mecanismos de controle de sua regularidade.

\section{XII.3 As regras da Lei 8.666}

284. A Lei Geral de Licitações, além de reconhecer a publicidade como um princípio essencial da atividade contratual da Administração Pública, também assegurou o direito dos interessados em obter acesso a informações específicas.

\section{XII.3.1 A regra específica do art. 63}

285. Existe regra específica no art. 63 da Lei de Licitações, tal como abaixo reproduzido:

É permitido a qualquer licitante o conhecimento dos termos do contrato e do respectivo processo licitatório e, a qualquer interessado, a obtenção de cópia autenticada, mediante o pagamento dos emolumentos devidos. 
286. Não se contraponha que o dispositivo alude a licitante e a processo licitatório, o que excluiria o acesso de informações às hipóteses de contratação direta. Éevidente queo art. 63 deve ser interpretado amplamente, especialmente porque a ausência de licitação incrementa os riscos de comprometimento da publicidade.

287. Mais ainda, a restrição da publicidade no caso de contratações diretas configuraria violação à Constituição. Passaria a existir uma categoria de contratos administrativos sigilosos: seriam aqueles em que não ocorreu licitação. Segundo essa interpretação, contratos de pequeno valor, abrangidos nas hipóteses dos incs. I e II do art. 24 da Lei de Licitações, tornar-se-iam sigilosos - tese que beira ao absurdo e acarreta riscos insuportáveis para a Nação brasileira.

288. É evidente que o art. 63 da Lei 8.666 referiu-se à licitação sob o pressuposto de que, como regra, os contratos administrativos são precedidos de um procedimento licitatório. Mas todos os cidadãos são legitimados a pleitear as informações sobre o contrato, independentemente da existência de uma licitação prévia.

\section{XII.3.2 As hipóteses de risco à segurança nacional}

289. A restrição à obtenção de informações apenas pode ser admitida nas hipóteses em que a dispensa de licitação fundar-se em que a própria publicidade acarreta risco à segurança nacional. Essa hipótese foi prevista no art. 24, inc. IX, da Lei 8.666.

\section{XII.3.3 Ainda a garantia quanto ao controle}

290. Por outro lado, a Lei 8.666 atribuiu aos interessados instrumentos para provocar o controle da regularidade dos contratos administrativos. No art. 113 , $\$ 1^{\circ}$, foi assegurado o direito de representação ao Tribunal de Contas:

Qualquer licitante, contratado ou pessoa física ou jurídica poderá representar ao Tribunal de Contas ou aos órgãos integrantes do sistema de controle interno contra irregularidades na aplicação desta Lei, para os fins do disposto neste artigo. 
291. Aliás, o TCU reiteradamente reconheceu a vedação ao sigilo relativamente aos contratos administrativos. Nesse sentido, há julgado em que foi afirmado o seguinte:

A afirmação do responsável de que o texto da cláusula, in fine, permite, mediante determinação legal ou judicial, o fornecimento a terceiros das informações referentes aos contratos, não elimina a irregularidade do texto já que, em princípio, a possiblidade de acesso aos termos de qualquer contrato por determinação judicial é inerente ao Estado de Direito, vigente no Brasil (Acórdão 537/2006, 2 ${ }^{\mathrm{a}}$ C., rel. min. Walton Alencar).

XII.4 A Lei 12.527

292. A Lei de Acesso à Informação (Lei 12.527/2011) regulamentou os dispositivos constitucionais.

\section{XII.4.1 O art. 39 da Lei 12.527}

293. Deve-se ter em vista o disposto no art. $3^{\circ}$ da Lei 12.527 , que estabelece o parâmetro norteador do relacionamento entre a Administração Pública e a Nação. O dispositivo tem a seguinte redação:

Os procedimentos previstos nesta Lei destinam-se a assegurar o direito fundamental de acesso à informação e devem ser executados em conformidade com os princípios básicos da administração pública e com as seguintes diretrizes: I - observância da publicidade como preceito geral e do sigilo como exceção; II - divulgação de informações de interesse público, independentemente de solicitações;

III - utilização de meios de comunicação viabilizados pela tecnologia da informação;

IV - fomento ao desenvolvimento da cultura de transparência na administração pública;

$V$ - desenvolvimento do controle social da administração pública. 
294. Evidentemente, essa disciplina não se constitui em letra morta, nem pode ser considerada como irrelevante.

XII.4.2 A regra do art. 79, inc. VI, da Lei 12.527

295. A preocupação em eliminar dúvidas conduziu a Lei a explicitar as hipóteses específicas de sua aplicação. Para os fins do presente parecer, é relevante destacar o art. $7^{\circ}$, inc. VI, adiante reproduzido:

O acesso à informação de que trata esta Lei compreende, entre outros, os direitos de obter:

$\cdots$

VI - informação pertinente à administração do patrimônio público, utilização de recursos públicos, licitação, contratos administrativos; ...

296. Os contratos administrativos, precedidos ou não de licitação (ou de qualquer procedimento seletivo), traduzem a aplicação de recursos públicos. Qualquer interessado é titular do direito fundamental a ter acesso às informações pertinentes.

\section{XII.4.3 A ressalva do $\$ 19$ do art. 79 da Lei 12.527}

297. Anote-se que a Lei preocupou-se em limitar o acesso às informações nas hipóteses em que o sigilo se configurar como necessário. $\mathrm{O} \S 1^{-0}$ do mesmo art. $7^{\mathrm{o}}$ estabeleceu a seguinte determinação:

O acesso à informação previsto no caput não compreende as informações referentes a projetos de pesquisa e desenvolvimento científicos ou tecnológicos cujo sigilo seja imprescindível à segurança da sociedade e do Estado.

298. É evidente que o dispositivo não restringiu o acesso a informações pertinentes a todo e qualquer projeto de pesquisa e desenvolvimento científico ou tecnológico. Essa limitação verifica-se apenas nas hipóteses em que tais atividades exigirem sigilo como indispensável à segurança da sociedade e do Estado. 
299. Também é inquestionável a ausência de autonomia da autoridade administrativa para qualificar uma situação concreta como envolvendo sigilo indispensável à segurança da sociedade e do Estado. Não existe uma competência discricionária quanto à qualificação jurídica de tais situações.

300. É indispensável um vínculo de causalidade efetivo entre o sigilo e a preservação da segurança.

\section{XII.4.4 A ressalva do $\$ 2$ ? do art. 79 da Lei 12.527}

301. É fundamental destacar que a eventual existência de alguma informação sigilosa não legitima a negativa de informação sobre outros aspectos da atividade administrativa. Existe determinação expressa sobre o tema, no $\S^{2} \underline{ }$ do mesmo art. $7^{\circ}$, tal como exposto a seguir:

Quando não for autorizado acesso integral à informação por ser ela parcialmente sigilosa, é assegurado o acesso à parte não sigilosa por meio de certidão, extrato ou cópia com ocultação da parte sob sigilo.

302. Por exemplo, é ilegal negar as informações sobre a quantidade e valor de produtos, prazos contratuais e outras informações invocando a existência de um segredo industrial no tocante à composição química de um medicamento.

303. Ou seja, a existência de informação protegida pelo sigilo não torna a atividade administrativa imune à publicidade.

\section{XII.4.5 As regras dos arts. 23 e seguintes da Lei 12.527}

304. Até para evitar práticas que frustrassem as finalidades legais, a própria Lei de Acesso à Informação disciplinou os pressupostos e o procedimento pertinente ao sigilo. Tal se encontra nos arts. 23 e seguintes.

305. No art. 23, estão expressos os pressupostos para a configuração da informação como imprescindível à segurança da sociedade ou do Estado.

306. No art. 24, está prevista a classificação da informação como ultrassecreta, secreta ou reservada. No art. 28, prevê que a classificação far-se-á por meio de decisão específica. A questão foi regulamentada por meio do Decreto $7.845 / 2012$, que previu as formalidades pertinentes. 


\section{XII.5 As PDPs e a Lei de Acesso à Informação}

307. As soluções admitidas e as práticas concretas desenvolvidas pela Administração Pública no âmbito de PDPs estão subordinadas à Lei de Acesso à Informação.

\section{XII.5.7 A dimensão infralegislativa da figura}

308. A PDP se constitui numa figura infralegal que envolve a aplicação de recursos públicos vultosos por meio de ajustes contratuais.

309. Ou seja, nem mesmo é cabível invocar a existência de algum dispositivo legal prevendo soluções diferenciadas daquelas pertinentes à disciplina genérica da atividade contratual do Estado.

\section{XII.5.2 A ausência de presunção de necessidade de sigilo}

310. Nem seria cabível invocar uma presunção geral no sentido de que toda e qualquer atividade de desenvolvimento dos medicamentos demandaria sigilo, sob pena de comprometimento da segurança nacional.

311. Até se pode admitir que, em algumas hipóteses, tal se verifique. Mas essa situação não poderá ser generalizada. Tal como já apontado, a exigência do sigilo deverá ser evidenciada concretamente, mediante a indicação das razões pertinentes em face da informação solicitada.

\section{XII.5.3 Os limites do sigilo}

312. Mais ainda, estarão submetidas ao regime de divulgação todas as informações não relacionadas diretamente com o risco de comprometimento da segurança nacional. Mesmo nas hipóteses em que o sigilo se fizer necessário, será ele aplicado nos limites correspondentes. Ou seja, todas as informações que não coloquem em risco a segurança deverão necessariamente ser divulgadas. 


\section{XII.5.4 O procedimento formal de reconhecimento do sigilo}

313. De qualquer modo, a restrição à divulgação das informações abrangidas no âmbito de PDPs depende da adoção do procedimento formal previsto no Decreto 7.845. Sem a observância das regras ali previstas, nenhuma informação poderá ser qualificada como ultrassecreta, secreta ou reservada.

314. Acresce que o art. 48 do referido Decreto 7.845 disciplinou inclusive a formalização de contratos sigilosos. Evidentemente, o dispositivo aplica-se inclusive às PDPs.

\section{XII.5.5 O dever de publicidade quanto à motivação}

315. Anote-se que a motivação do ato administrativo que reconhece a presença dos requisitos para o sigilo não é albergada pelo dito sigilo. Não se confunde a informação sigilosa com o reconhecimento da sua existência.

316. Deve-se ter em vista que a publicidade é um princípio fundamental. Existem hipóteses em que se admite a restrição à sua aplicação. Mas o ato administrativo que proclama a existência do sigilo não está acobertado também ele pelo sigilo.

\section{XIII - O caso concreto: condutas orientadas a práticas vedadas}

317. A existência de patente de invenção produz efeitos inibitórios de qualquer conduta concreta orientada a violar os direitos assegurados ao titular. Essa disciplina aplica-se inclusive à PDP que tenha por objeto medicamento que faz uso de invento objeto de patente.

\section{XIII.1 O descabimento de PDP quanto a medicamento patenteado}

318. O regime jurídico vigente é incompatível com uma PDP versando sobre medicamento que faz uso de invenção protegida por patente. 


\section{XIII.1.1 A PDP e a inevitável infração à patente}

319. O modelo jurídico da PDP implica que, versando sobre medicamento protegido por patente, a implementação dependa da concordância do titular. Em tais hipóteses, o procedimento de pactuação da PDP compreende atos jurídicos que conduziriam necessariamente violação aos direitos do titular da patente.

320. A irregularidade se configuraria na formulação de proposta de PDP nos termos do art. 14 da Portaria 2.531/2014, eis que haveria oferta de venda de produto objeto de patente. $\mathrm{O}$ mesmo se passaria com as diversas vendas ocorridas durante a vigência da PDP, o que seria agravado nas hipóteses em que ocorresse importação do produto objeto da PDP.

\section{XIII.1.2 O descabimento do argumento da relevância do medicamento}

321. Como é evidente, é absolutamente impertinente o argumento da relevância do medicamento a ser produzido. Essa questão já foi resolvida pelo direito brasileiro, ao assegurar a proteção por meio de patente de invenção sem distinção quanto a produtos farmacêuticos, muito menos quanto aqueles relacionados a medicamentos relevantes.

\section{XIII.1.3 O descabimento do uso da PDP para violar patentes de invenção}

322. Ou seja, a PDP não se constitui em instituto jurídico destinado a frustrar os direitos de patente. Um dos pressupostos de validade da constituição de uma PDP é a inexistência de patente de invenção que proteja produto ou processo farmacêutico relacionado ao medicamento a ser produzido, ou a autorização do seu titular. Isso resta claro, ainda, da leitura do art. 14, III, a) e b) da Portaria 2.531/2014. 


\section{XIII.1.4 O descabimento do sigilo para ocultar a ilegalidade}

323. Muito menos cabível seria invocar o sigilo para evitar a revelação da prática de ilicitude. Não há fundamento jurídico para negar toda e qualquer informação pertinente a uma PDP, em especial as de caráter eminentemente público como preço, quantidade e prazo para a venda do produto, visando impedir a exposição pública das condutas infringentes do direito de patente assegurado pela lei.

\section{XIII.2 O caso concreto: a oferta da PDP}

324. A proposta de projeto de PDP versando sobre um medicamento que implementa invenção objeto de patente, sem a aquiescência do seu titular, configura infração tanto ao art. 42 como ao artigo 184 da Lei 9.279/96.

\section{XIII.2.1 A configuração de colocação à venda}

325. A existência de uma PDP envolve uma manifestação externa de vontade que se caracteriza como uma "colocação à venda". Existe um sujeito que apresenta à Administração Pública um projeto de atuação orientado necessariamente à venda de objeto determinado. Assim se passa porque, como visto, a finalidade necessária de uma PDP é a comercialização de um produto específico.

326. Uma proposta de projeto de PDP consuma a conduta de colocar à venda o produto porque o sujeito anuncia a sua disposição de promover futuramente a comercialização do produto protegido pela patente.

\section{XIII.2.2 A definição inerente de compra e venda}

327. Ressalte-se que, aprovado o projeto da PDP e formalizado o contrato, a providência subsequente é a formalização de uma compra entre o Ministério da Saúde e a instituição pública do medicamento. Essa operação é precedida da compra realizada pela instituição pública em face da entidade privada. 328. Portanto, a compra e venda do medicamento objeto de proteção por patente é uma decorrência inerente à PDP. 


\section{XIII.2.3 A irrelevância dos trâmites envolvidos}

329. Tal como exposto acima, a solução legislativa abarca amplamente todas as condutas por meio das quais alguém acena com a venda de um objeto compreendido na tutela de patente de invenção. A circunstância de que a futura venda ocorrerá em momento futuro e dependerá de uma série de atividades e trâmites é juridicamente irrelevante. A Lei não restringe a reprovabilidade à conduta consistente em oferta efetivamente aceita nem depende da consumação da compra propriamente dita.

330. Por outro lado, a circunstância de que a comercialização do produto será antecedida de sua fabricação futura não descaracteriza a colocação à venda.

\section{XIII.2.3 A irrelevância de eventual condição suspensiva}

331. Para ser mais preciso, a conduta de "colocar à venda" continua a se caracterizar mesmo quando existir uma condição suspensiva - qual seja a eventual aceitação de um projeto de fabricação pelo destinatário.

332. O sujeito que comparece perante outro e lhe oferece o fornecimento de um produto, cuja fabricação dependerá de um concerto de vontade entre ambos, está a praticar uma "colocação à venda". Assim se passa porque existe uma manifestação de vontade de promover a comercialização do produto, ainda que a sua existência seja futura.

\section{XIII.2.5 A configuração dos ilícitos do art. 42 e do art. 184}

333. A análise teórica realizada induz a presença de requisitos para a consumação das infrações previstas no art. 42 e no art. 184 da Lei 9.279. A conduta de manifestar a vontade de promover uma futura alienação de medicamento objeto de patente de invenção, mediante os trâmites da contratação administrativa, apresenta os requisitos potenciais dos ilícitos já referidos. 


\section{XIII.3 O caso concreto: a previsão da produção}

334. Por outro lado, a PDP se constitui em um instrumento jurídico para a produção de medicamentos (ou outros produtos contemplados na respectiva política de governo).

\section{XIII.3.1 A parceria como instrumento para a produção}

335. Uma PDP envolve uma proposta de produção de um medicamento. Isso significa que a execução da PDP acarreta, de modo inafastável, a atividade de produção do medicamento pela instituição pública com o apoio da entidade privada através da transferência de tecnologia e assessoramento. Se o objeto a ser produzido estiver acobertado por uma patente, a cogitação e a efetiva existência da PDP configurarão conduta subsumível ao previsto no art. 42.

\section{XIII.3.2 A previsão de produção futura}

336. A tutela legal compreende inclusive as atividades orientadas à produção. Ou seja, não é cabível argumentar que, enquanto não houver a produção material efetiva, não existiria infração à patente.

\section{XIII.3.3 A gravidade da conduta: a associação com ente estatal}

337. A questão apresenta especial gravidade porque a PDP configura uma associação para a produção do medicamento. Isso significa a conjugação de esforços entre a instituição pública e a entidade privada, que coordenarão a sua atuação harmônica para permitir que a instituição pública produza o medicamento.

338. Ora, a existência de proteção patentária para a invenção implementada pelo medicamento objeto da PDP implica que a conduta reprovável será consumada pela atuação conjugada entre os diversos parceiros da PDP. Não caberá diferenciar entre eles, para afirmar que a atividade ilícita consiste apenas na fabricação material. É evidente que a produção, no caso da PDP, é uma atividade juridicamente imputável a todos os parceiros. 


\section{XIII.4 O caso concreto: a consumação da promessa de venda}

339. Outra ilicitude consiste na previsão de vender os produtos a serem produzidos por meio da PDP.

\section{XIII.4.1 A promessa de compra e venda}

340. A PDP envolve uma promessa de compra e venda dos produtos, consubstanciada na proposta de Projeto de PDP, abarcada tanto pelo conceito de "oferta à venda" como pelo conceito mais amplo de "colocação à venda". A Administração Pública compromete-se a adquirir o produto resultante da atuação concertada, o que se constitui em solução jurídica essencial para a aplicação dos esforços e recursos públicos (e, eventualmente, privados) necessários ao desenvolvimento da PDP.

341. Anote-se que a contratação da PDP envolve a definição de todas as condições relativas às compras a serem feitas pela Administração Pública durante a vigência da PDP, inclusive definição do objeto, quantitativos e preços.

342. Essa interpretação funda-se no texto da própria Portaria 2.531, que estabelece os seguintes requisitos para uma proposta de Projeto de PDP (art. 14, VIII, a):

Art. 14. A elaboração de proposta de projeto de PDP observará as seguintes diretrizes:...

VIII - quanto à proposta de preço de venda e estimativa da capacidade de oferta:

a) serão apresentadas propostas com os valores unitários anuais em termos nominais e a capacidade de oferta anual do produto para o período do projeto; ...

343. Ainda, veja-se a definição no art. $2^{\mathbf{0}}$ :

XIV - termo de compromisso: documento firmado entre a instituição pública, que se responsabiliza pelo investimento, desenvolvimento, transferência e absorção de tecnologia de produtos estratégicos para o SUS, e o Ministério da Saúde, que se responsabiliza pela aquisição dos produtos objetos da PDP, contendo em anexo declaração de concordância com o referido documento subscrita pelos parceiros privados; ... 
344. Segundo o art. 35 da Portaria 2.531, o termo de compromisso será formalizado após a aprovação da proposta de projeto. E, como determina o art. 43 do mesmo diploma, "Após a assinatura do termo de compromisso, inicia-se a fase do projeto de $P D P^{\prime \prime}$.

345. Então, o "termo de compromisso" formaliza a obrigação do Ministério da Saúde de comprar o medicamento da instituição pública e, consequentemente, da entidade privada durante a vigência da PDP ("que se responsabiliza pela aquisição dos produtos objetos da PDP"). Esse termo de compromisso é acompanhado de uma declaração de concordância do parceiro privado, que se torna vinculado às condições previstas.

\section{XIII.4.2 A equivalência jurídica entre as operações}

346. Sob o prisma jurídico, a promessa de compra e venda produz efeitos muito próximos às da compra e venda propriamente dita. Em muitas hipóteses, assegura-se às partes exigirem a emissão da vontade inerente ao contrato principal. Há casos em que a promessa de compra e venda é suficiente para assegurar às partes as prestações previstas. Assim está previsto no próprio art. 463 do Código Civil, que estabelece o seguinte:

Concluído o contrato preliminar, com observância do disposto no artigo antecedente, e desde que dele não conste cláusula de arrependimento, qualquer das partes terá o direito de exigir a celebração do definitivo, assinando prazo à outra para que o efetive.

\section{XIII.4.3 A promessa de venda e a futura venda}

347. Sendo ilícita a colocação à venda e a própria venda, é evidente que também é ilícita a promessa de compra e venda. Ou seja, não caberia argumentar que a infração à patente apenas ocorreria no momento futuro, em que viesse a ser consumada a venda propriamente dita. 


\section{XIII.5 A conduta de importar}

348. Anote-se que uma das alternativas previstas no âmbito das PDPs envolve a importação dos medicamentos do estrangeiro. Evidentemente, a importação do medicamento objeto de patente constitui um ilícito específico. Se vier a ocorrer, consumará a infração e tipificará a prática de crime.

\section{XIII.6 Sintese}

349. A submissão de uma proposta de projeto de PDP ao Ministério da Saúde pela instituição pública e entidade privada, quando envolver medicamento que implementa invenção objeto de patente, configura colocação à venda do produto e, consequentemente, infração à patente. As providências subsequentes, com a formalização do termo de compromisso, traduzem condutas orientadas à consumação das demais infrações previstas nos arts. 42 e 184 da Lei 9.279.

\section{XIV - O caso concreto: a legalidade administrativa}

\section{XIV.7 Vedação à participação pela Administração}

350. A questão também pode ser examinada sobre o prisma do regime de direito público, que acarreta vedação à participação pela Administração em qualquer conduta contratual apta a violar o direito.

\section{XIV.1.1 A vedação à atuação administrativa concorrente para infração}

351. Mas o regime de direito administrativo apresenta implicações muito relevantes no tocante à proteção decorrente de patentes de invenção. É vedado à autoridade pública atuar de modo a concorrer para a infração a tais direitos. 352. A proibição de o agente estatal violar a ordem jurídica implica a vedação à sua participação em práticas conducentes a um resultado antijurídico. A Administração Pública não dispõe de autonomia para engajar-se em negociação que resultará em infração aos direitos do titular da patente. 


\section{XIV.1.2 Ainda a rejeição à tese da infração isolada pelo terceiro}

353. Nem caberia contrapor que a vedação incidiria "apenas" sobre o terceiro que "produz" indevidamente o objeto compreendido na tutela da patente. Essa argumentação não pode ser admitida em vista da Administração Pública, eis que concorrer para a prática de ilicitude (penal, inclusive) constitui-se em violação à exigência de legalidade da atividade administrativa.

354. Vale destacar que o $\$ 1^{\circ}$ do art. 42 da referida Lei configura como reprovável inclusive a conduta de "contribuir" para a prática do ilícito, tal como adiante reproduzido:

Art. 42. A patente confere ao seu titular o direito de impedir terceiro, sem o seu consentimento, de produzir, usar, colocar à venda, vender ou importar com estes propósitos:

I - produto objeto de patente;

II - processo ou produto obtido diretamente por processo patenteado.

$\S 1^{\circ}$ Ao titular da patente é assegurado ainda o direito de impedir que terceiros contribuam para que outros pratiquem os atos referidos neste artigo.

\section{XIV.2 A exigência da licitude de objeto}

355. Senãofosse suficientea submissão da atividadeadministrativaàlegalidade, incidiria a exigência da licitude do objeto do contrato administrativo.

\section{XIV.2.1 A licitude do objeto contratual}

356. O contrato administrativo subordina-se às regras gerais contidas no art. 104 do Código Civil, que determina, no inc. II, o seguinte:

$$
\begin{aligned}
& \text { A validade do negócio jurídico requer: } \\
& \text { I- ... } \\
& \text { II - objeto lícito, possível, determinado ou determinável; ... }
\end{aligned}
$$




\section{XIV.2.2 A contratação administrativa}

357. As peculiaridades do regime de direito público, que afetam a contratação administrativa, não conduzem à viabilidade de contratação versando sobre uma prestação contrária à ordem jurídica.

358. Aliás, o regime da atividade administrativa exige que o objeto a ser executado não contemple qualquer violação à ordem jurídica.

\section{XIV.2.3 A contratação administrativa ilícita}

359. Por isso, existe uma vedação insuperável à hipótese de a Administração Pública adquirir objeto fornecido com violação a patente de invenção. Assim se passa porque a prestação a ser executada pelo terceiro constituir-se-ia numa ilicitude. Portanto, o objeto do contrato seria contrário ao Direito. Logo, o contrato seria inválido.

\section{XIV.3 Ainda a ausência de autonomia de escolha para a Administração}

360. A vedação à contratação de terceiro, em hipótese de objeto protegido por patente de invenção, traduz-se inclusive no procedimento contratual a ser observado pela Administração Pública.

\section{XIV.3.1 A inexigibilidade de licitação}

361. O art. 25, inc. I, da Lei 8.666 determina que, existindo direito de exclusividade sobre o objeto de que necessita a Administração Pública, é obrigatória a contratação com o seu titular. O dispositivo tem a seguinte redação:

É inexigível a licitação quando houver inviabilidade de competição, em especial: I - para aquisição de materiais, equipamentos, ou gêneros que só possam ser fornecidos por produtor, empresa ou representante comercial exclusivo, vedada a preferência de marca, ...; 
362. A inexigibilidade de licitação prevista no dispositivo acima transcrito reflete o reconhecimento de que, em tais hipóteses, não existe viabilidade de a Administração selecionar outro fornecedor - senão aquele que é titular do direito de exclusividade.

\section{XIV.3.2 A ausência de pluralidade de alternativas}

363. Quando o objeto de que a Administração necessitar for abrangido em patente de invenção, a única alternativa consiste em contratar o fornecimento como titular da patente de invenção ou obter o consentimento dele para formalizar um negócio com terceiro.

364. A Lei 8.666 autoriza, em tais hipóteses, a contratação direta, sem a realização do procedimento licitatório prévio. A inexigibilidade de licitação, nas hipóteses examinadas, decorre da vedação jurídica à contratação com um terceiro.

\section{XV - Considerações complementares}

365. Não caberia contrapor que a solução da PDP foi adotada pela Administração Pública como uma alternativa à intransigência da Consulente, nem que se trata de uma preparação para momento posterior à extinção do prazo de validade da patente em questão.

\section{XV.1 A impertinência dos dois argumentos}

366. Antes de tudo, ambos os argumentos seriam impertinentes. O regime jurídico de proteção à patente não é afastado pela presença de qualquer dos dois argumentos antes referidos.

367. No entanto e ainda que assim não o fosse, as evidências concretas demonstram a sua improcedência. 


\section{XV.2 A disposição da Consulente em participar da PDP}

368. A Consulente narrou a sua disponibilidade em participar de uma PDP com a Administração Pública brasileira.

\section{XV.2.1 A escolha de outrem}

369. A Administração Pública nem sequer buscou a Consulente no momento inicial da constituição da PDP, não obstante a titularidade da patente indispensável à produção do medicamento. Houve a escolha de outro parceiro.

\section{XV.2.2 A ausência de motivação da decisão}

370. A Consulente acrescentou que os motivos da decisão adotada no caso concreto não foram fornecidos. Mais ainda, a Consulente destacou que todo o procedimento da PDP é mantido em sigilo pelos órgãos competentes.

\section{XV.2.3 A recusa ao fornecimento de informações}

371. Ademais, houve recusa de fornecimento das informações solicitadas pela Consulente, que não teve acesso a qualquer elemento relativo à contratação, inclusive no tocante a preços e quantidades.

\section{XV.3 A inviabilidade da tese da preparação}

372. Sob outro enfoque, a tese do desenvolvimento de atividades preparatórias para a fabricação do medicamento posteriormente ao encerramento do prazo de vigência da patente é inviável.

\section{XV.3.1 Ainda a violação à patente}

373. A infração à patente ocorre quando os atos são praticados durante a vigência dela. Portanto, a oferta à venda (consubstanciada na proposta de 
projeto de PDP) em momento presente de um medicamento objeto de patente é suficiente para configurar a infração.

\section{XV.3.2 A data de outorga da patente}

374. Por outro lado, a patente foi concedida em ..., com prazo de dez anos. Ou seja, a patente terá vigência até ....

\section{XV.3.3 A inviabilidade de promover PDP com tal antecedência}

375. Não é plausível admitir que uma PDP seria contratada no momento atual para ser executada (início da etapa de transferência da tecnologia, venda do medicamento etc.) mais de ... anos depois. Essa argumentação tenderia à violação ao princípio da eficiência na gestão dos recursos públicos, além de infringir a razoabilidade.

\section{$\mathrm{XVI}$ - Conclusão}

376. Em face dos pressupostos acima alinhados, apresento as seguintes respostas para os quesitos formulados.

a) O direito brasileiro assegura ao titular de patente de invenção, durante seu prazo de vigência, o direito de impedir terceiros de produzir, usar, colocar à venda, vender ou importar com estes propósitos (art. 42 da LPI), bem como de fabricar (art. 183 da LPI), exportar, vender, expor ou oferecer à venda, ter em estoque, ocultar ou receber, para utilização com fins econômicos (art. 184 da LPI), medicamento que faz uso de invento objeto de patente?

Resposta: Sim. A Lei 9.279 contempla a tutela ampla à propriedade industrial, prevendo a figura da patente de invenção e estabelecendo os direitos conferidos ao seu titular, dentre os quais se encontra aquele de impedir terceiros de produzir, usar, colocar à venda, vender ou importar com estes propósitos, conforme art. 42 da LPI, bem como de fabricar, exportar, vender, expor ou oferecer à venda, ter em estoque, ocultar ou receber, para utilização com fins 
econômicos - arts. 183 e 184 da LPI, esses últimos tipificados como crimes contra propriedade industrial.

b) A oferta à venda de medicamento que faz uso de um invento que é objeto de patente, quando não envolve o seu titular ou agente legitimamente autorizado (i.e. por meio de licença), configura ato jurídico ilícito?

Resposta: Sim. A Lei 9.279 contempla um elenco de condutas diversas como ilícitas, quando versam sobre produto objeto de patente, desde que realizadas sem a aquiescência do titular. Essas condutas são qualificadas como ilícitas de modo autônomo, independentemente da consumação de um dano econômico ou moral ao titular da patente. Para os efeitos do direito brasileiro, a conduta isolada de oferecer à venda um medicamento objeto de patente, sem a concordância do seu titular, configura prática ilícita - tanto sob o prisma não penal como no âmbito penal.

c) No direito brasileiro, em que a oferta à venda de produto objeto de patente é autonomamente tipificada como crime (art. 184 da LPI) e ato ilícito civil (art. 42 da LPI), a configuração da ilicitude requer a comprovação de que a venda se consumaria na vigência da patente ou a oferta à venda já caracteriza per se infração ao direito patentário?

Resposta: A oferta à venda consuma a ilicitude, independentemente da circunstância de que a venda venha ou não a ser efetivamente realizada. A Lei brasileira é clara e incondicionada nesse ponto. Não existe qualquer restrição relacionada ao curso dos eventos futuros. Nessa linha, a Lei brasileira não restringe a ilicitude apenas às hipóteses em que a oferta se refere à consumação da venda durante o período de vigência da patente.

d) A prática de atos como a importação, a fabricação e a manutenção em estoque de produto objeto de patente configura ato jurídico ilícito segundo a legislação brasileira, mesmo se a sua comercialização estiver programada para ocorrer apenas após finda a proteção patentária?

Resposta: Sim. Tal como afirmado acima, a repressão legal não é condicionada a eventos supervenientes. Os atos ilícitos apresentam natureza autônoma e a sua prática é suficiente para consumar a ilicitude. A eventual destinação à comercialização em momento futuro (posterior à extinção da patente) não exclui a ilicitude de condutas qualificadas como ilícitas, tal como a importação, a fabricação e a manutenção em estoque. 
e) É compatível com o direito brasileiro a celebração de PDP para a aquisição de medicamento que faz uso de invento objeto de patente e a transferência de tecnologia para sua produção, com terceiros não autorizados?

Resposta: Não. A existência de negociação de medicamento protegido por patente de invenção via PDP configura violação sob diversos ângulos aos direitos do titular dessa patente. A mera formulação de proposta de um projeto de PDP envolvendo um sujeito que não é titular da patente e que não conta com a concordância dele configura a conduta de oferta à venda, consumando o ilícito dos arts. 42 e 184 da Lei de Propriedade Industrial. Ademais, a modelagem da PDP implicará, de modo necessário e inafastável, a consumação de outros ilícitos reprimidos legalmente.

f) Uma proposta de PDP que cumpra com as diretrizes e requerimentos da Portaria 2.531 de 12 de novembro de 2014 do Ministério da Saúde, como aqueles elencados em seu artigo 14, VIII, configuraria uma "oferta à venda" nos termos da Lei 9.279/1996?

Resposta: Sim. O procedimento de contratação da PDP contempla diversas etapas. A primeira delas consiste na proposta de projeto, que, nos termos do art. 14, VIII, "a", necessita - além de identificar o produto objeto da PDP - discriminar os valores unitários anuais em termos nominais e a capacidade de oferta anual do produto para o período do projeto. Portanto, já é uma manifestação do oferecimento de comercialização de um determinado produto, consistindo tanto numa "oferta à venda" do medicamento como na sua "colocação à venda", para fins da Lei de Propriedade Industrial. Tal como exposto, a ilicitude não depende de o objeto já existir no momento da oferta, nem da prática de outro ato infracional, tal como a fabricação ou a venda propriamente dita, que somente viria a ocorrer em momento futuro. Nem depende que tais atos aperfeiçoar-se-ão mediante atuação concertada entre o ofertante e terceiros.

g) A formalização e ratificação de proposta de PDP aprovada, por meio da assinatura de Termo de Compromisso (art. 35 da Portaria 2.531), evidencia o aceite da "oferta à venda" nos termos da Lei 9.279/1996?

Resposta: Sim. O Termo de Compromisso é o instrumento previsto para a formalização da aprovação pelo Ministério da Saúde da proposta de PDP apresentada pela instituição pública e entidade privada. É através dele que o Ministério da Saúde formalmente aceita a oferta à venda contida na proposta de projeto de PDP. 
O termo de compromisso reflete exatamente os termos da proposta de projeto de PDP apresentada, vinculando formalmente as partes (entre as quais, o Ministério da Saúde). Após a assinatura do Termo de Compromisso, a instituição pública e a entidade privada passarão a executar as condutas a que se obrigaram, inclusive para o efeito de formalizar os detalhes das obrigações relativas à transferência da tecnologia e ao fornecimento do medicamento perante o Ministério da Saúde.

É o parecer.

Brasília, julho de 2018.

Marçal Justen Filho

Doutor em Direito

$\mathrm{OAB} / \mathrm{DF} 34.390$ 